\begin{tabular}{||l|l||}
\hline Citation & $\begin{array}{l}\text { Chatelain, G; Schepers, Guido; Rozenski, Jef; Van Aerschot, Arthur (2012), } \\
\text { Hybridization potential of oligonucleotides comprising 3'-O-methylated } \\
\text { altritol nucleosides } \\
\text { Mol. Divers., 16 825-837 }\end{array}$ \\
\hline Archived version & This is the Post print version of the manuscript \\
\hline Published version & http://dx.doi.org/10.1007/s11030-012-9402-1 \\
\hline Journal homepage & $\begin{array}{l}\text { http://link.springer.com } \\
\text { Arthur.Vanaerschot@rega.kuleuven.be } \\
+32(0) 16372624\end{array}$ \\
\hline $\begin{array}{l}\text { Anthor contact } \\
\text { https://lirias.kuleuven.be/handle/123456789/368979 }\end{array}$ \\
\hline
\end{tabular}

(article begins on next page) 


\title{
HYBRIDIZATION POTENTIAL OF OLIGONUCLEOTIDES COMPRISING 3'-O-METHYLATED ALTRITOL NUCLEOSIDES
}

\author{
G. Chatelain, G. Schepers, J. Rozenski and A. Van Aerschot* \\ Laboratory for Medicinal Chemistry, Rega Institute for Medical Research, KU Leuven, \\ Minderbroedersstraat 10, BE-3000 Leuven, Belgium.
}

* Corresponding author: Dr. Arthur Van Aerschot, Rega Institute for Medical Research, KU Leuven, Minderbroedersstraat 10, BE-3000 Leuven, Belgium

E-mail address: arthur.vanaerschot@rega.kuleuven.be

Tel.: +3216337388

Fax: +3216337340

Keywords: oligonucleotides, hexitol nucleic acids, siRNA, antisense, hybridisation, solid phase synthesis 


\begin{abstract}
:
A series of 3'-O-methylated D-altrohexitol nucleoside analogs (MANA) was synthesized comprising all four base moieties, adenine, cytosine, uracil and guanine. These monomers were incorporated into oligonucleotides (ONs) by automated solid phase synthesis and the thermal and thermodynamic stability of all new modified constructs were evaluated. Data were compared with results obtained for both anhydrohexitol (HNAs) and 3'-O-altrohexitol modified ONs (ANAs). We hereby demonstrate that ONs modified with MANA monomers have an improved thermal and thermodynamic stability compared to RNA, ANA or HNA containing ONs of which the extent depends on the number of incorporated moieties and their position in the sequence. Thermodynamic analysis afforded comparable or even improved results in comparison with the incorporation of locked nucleic acids. While the specificity of these new synthons is slightly lower compared to mismatches within RNA double strands, it is similar to the discrimination potential of other hexitol modifications (HNA and ANA) which already proved their biologic interest, highlighting the potential of MANA constructs in antisense and in siRNA applications.
\end{abstract}




\section{Introduction}

Modulation of gene expression is a continuously growing research area and can be attained by interfering with transcription or translation processes. The use of RNA interference (RNAi)-based strategies has recently become the technique of choice to silence gene expression in mammalian cell culture [1]. In typical strategies, 21-base pairs double stranded RNA (dsRNA) molecules, termed short interfering RNAs (siRNAs), with perfect complementarity to the target RNA are used as experimental triggers of mRNA breakdown. Upon delivery into the cell, siRNAs are incorporated into the RNAinduced silencing complex (RISC) containing the signature component of the RNAi machinery, Argonaute 2 (Ago2) [2-4]. The siRNA strand containing the thermodynamically less stable 5'-end is preferentially incorporated as the guiding strand of RISC, while the non-guiding sense strand (SS) of the siRNA duplex is cleaved by Ago2 and discarded. This generates an activated RISC containing the guiding antisense strand (AS), binding the complementary target RNAs and leading to cleavage of the latter by Ago2. Whereas unmodified siRNAs are highly efficient in cell culture, chemical modification is generally considered as a prerequisite for fulfilling the potential of siRNAs in vivo and indeed successful experiments in animal models have relied on injection of chemically modified siRNAs [5]. A variety of strategies for siRNA modification have been pursued including alterations in the backbone chemistry [6], 2'-sugar modification [7], nucleobase modifications [8] and other means [9], as recently reviewed. Another way to address this problem is to assemble carbohydrate-modified ONs, exemplified by hexitol nucleic acids [10-14], 2'-O-(2-methoxy)ethyl ONs [15,16] and bicyclic ONs [17], with the LNA monomers of the Wengel group [18] showing the strongest affinity for RNA, and having many alternative structures [19]. The strong hybridization characteristics between these structures and complementary RNA are generally attributed to the formation of a preorganized conformation, fitting the A-form of dsRNA, with strong stacking interactions between the bases, adequate interaction of the latter in a Watson-Crick type geometry with their complement, and 
efficient hydration of the double-stranded helix [20]. More recently, the structural analysis and biological effects of nucleic acids with in particular a six-membered carbohydrate mimic in the backbone, have been discussed [21]. Likewise, the advantages of these hexitol containing constructs were illustrated.

Hexitol nucleic acids (HNA, Fig. 1) are composed of phosphorylated 2,3-dideoxy-D-arabino-hexitol units with a nucleobase situated in the 2-(S)-position. They hybridize sequence selectively with RNA in an antiparallel way. We observed that the increase in Tm per modification of an HNA:RNA duplex versus duplexes of natural nucleic acids is sequence and length dependent [22]. HNA is an efficient steric-blocking agent, as observed during investigations of HNA in cell free translation experiments (giving IC50 values of $50 \mathrm{nM}$ as inhibitors of Ha-ras mRNA translation) [23].

However, a further increase in affinity would widen their applicability. The D-altritol nucleic acid (ANA) analogs $[12,24,25]$ of HNA with a supplementary hydroxyl at the $3^{\prime}$ - $\alpha$-position have already paved the way and strong biological effects were noted for ANA containing constructs for the siRNA field. The underlying reason for the duplex stabilization effect of the supplementary $\mathrm{OH}$ group in an ANA:RNA hybrid has been highlighted very recently [26]. A further increase has been demonstrated in the past upon alkylation of this hydroxyl moiety in case of the uridine analog [27], in analogy with the duplex stabilizing effects of 2'-O-alkylated RNA congeners $[28,29]$. Considering these preliminary results, all four 3'-O-methylated altritol building blocks 1a-d (Fig. 1) were evaluated for incorporation into RNA sequences in terms of their hybridizing potential and sequence selectivity with natural ONs.

\section{Results and Discussion}

\section{Synthesis of new 3'-O-methylated ANA phosphoramidite building blocks}

Synthesis of the 3'-O-methylated altritol monomers (MANA) is depicted in Fig. 2 and followed the pathway previously described for preparation of altrohexitol monomers [30]. Herein, ring opening of 
the 4,6-O-benzylidene-protected allitol epoxide (2) with uracil, adenine or 2-amino-6-chloropurine anions furnished the corresponding altrohexitol derivatives (3a, 3c and 3e) with 66-85\% yield. Chemoselective methylation without temporary protection of the nucleobases afforded $50 \%$ of the methylated nucleosides (4a, 4c and $\mathbf{4 e )}$ ). Methylation proceeded slowly but the yields were comparable to those reported previously for other altritol derivatives [27]. The slow reaction rate compared to the previously described methylations on ribonucleosides is probably caused by the axial location of the hydroxyl group. The selectivity of the methylation as carried out in THF, was easily confirmed by NMR and mass spectroscopy. In addition, small amounts of the respective bismethylated compounds (with concommittant methylation on the base moiety) were obtained, but were not further pursued. In contrast, reactions carried out in DMF turned out to be more base-selective. This was described recently also by Zerrouki and co-workers [31,32]. The cytosine derivative (4b) was obtained in one pot by conversion from the uracil congener (4a) in 70\% yield via its triazolide intermediate [33]. Baseprotection of $\mathbf{4 b}$ and $\mathbf{4 c}$ with a benzoyl group afforded $\mathbf{5 b}$ and $\mathbf{5 c}$ respectively, in $70 \%$ yield. The nucleobase of $4 \mathbf{e}$ was converted to guanine affording $\mathbf{4 d}$, followed by protection with the dimethylformamidine (dmf) moiety yielding $76 \%$ of $\mathbf{5 d}$ following standard protocols $[30,34]$. Deprotection of the benzylidene protecting group gave 6a-d, and further straightforward functionalization (dimethoxytritylation and phosphitylation) afforded the desired phosphitylated building blocks 8a-d, to be used for oligomer assembly (Fig. 3).

\section{Comparative thermal and thermodynamic analysis of duplexes containing one HNA, ANA or}

\section{MANA modification}

The new MANA analogs described in this manuscript were used for incorporation within stretches of RNA, as well as for homopolymer synthesis. All desired MANA oligonucleotide constructs were assembled on a propanediol-containing universal support [35], obviating the need for nucleoside modified supports. Previous studies indicated that 1,5-anhydrohexitol analogs with a $\beta$-C2 attached 
heterocyclic base moiety, show more resemblance to ribonucleosides. Therefore, incorporation of a single modification of a MANA monomer (either maU, maC, maA and maG as the respective 3'-Omethylated altritol congeners $\mathbf{8 a}, \mathbf{8 b}, \mathbf{8 c}$ and $\mathbf{8 d}$ ) into RNA ONs was studied with the aid of 9-mer RNA sequences 5'-GCGU-maX-UGCG-3'. The thermodynamic stability of the modified oligos obtained was evaluated versus the respective RNA complementary sequences. This allowed evaluation of the 3'-hydroxyl moiety as in ANA versus its 3'-O-methylated congener affording the MANA constructs. The modified analogs were incorporated within RNA sequences as shown in Table 1 . The UV melting curve analysis method was used to calculate the melting temperature (Tm) values, $\Delta H^{\circ}$, $\Delta S^{\circ}$ and $\Delta G^{\circ}{ }_{310}$ of folded duplexes. This method necessitates to calculate first the fraction of the single strand state and duplex state at each temperature $(\alpha(T))$ from the UV melting curves [36,37]. The complete method is described in the experimental section.

Introduction of MANA, ANA or HNA building blocks in the RNA sequences resulted in an increase of the thermal and thermodynamic stability of duplexes. The increase in melting temperature varied between +0.1 and $+4.0^{\circ} \mathrm{C}$ for a single modification. It has been documented that single modified ONs when incorporated into natural nucleic acids may induce local geometry changes over several neighboring base pairs. Strong hybridizing complexes were obtained, indicating a pre-organized structure fitting the A-type dsRNA duplex [10]. Remarkably, the higher affinity obtained is relatively lower for cytosine analogs $\left(+0.1<\Delta \mathrm{Tm}<+1.2^{\circ} \mathrm{C}\right)$ compared to the other base analogs $\left(+2.0<\Delta \mathrm{Tm}<+4.5^{\circ} \mathrm{C}\right)$. Considering the different hexitol congeners, purines and pyrimidines do not seem to behave likewise. With purines, the greater thermal affinity was obtained for altritol modifications versus HNA. The difference between HNA and ANA amounted to $0.5^{\circ} \mathrm{C}$ for $\mathrm{G}$ analogs and to $1.5{ }^{\circ} \mathrm{C}$ for the A analogs. Methylation of the supplementary 3'-OH of the altritol backbone further increased the thermal affinity by $0.5^{\circ} \mathrm{C}$ for a single modification. A representative figure comparing the effects for a single incorporation of the different modified adenosine analogues (HNA, ANA, MANA) is shown in Fig. 4, highlighting the improved affinity of the ON containing the MANA 
modification for its RNA complementary sequence. In the case of pyrimidines however, the ANA modification clearly stabilized the duplex, but the affinity for the RNA complementary sequence was surpassed by both HNA and MANA modifications. In addition, a large difference was noticed between $\mathrm{C}$ and $\mathrm{U}$ congeners. Although substitution with an altritol $\mathrm{U}$ modification (aU) increased the thermal stability of the duplex versus the natural RNA duplex by $2.6^{\circ} \mathrm{C}$, there was no significant increased affinity upon incorporation of the aC modification. This result is surprising and an explanation maybe needs to be sought in the neighboring base pairs and the sequence context.

A thermodynamic study of all modified duplexes confirmed the tendencies as seen in the thermal study, with increased affinity of hexitol modifications for RNA, hence corroborating the great interest to use HNA, ANA and more importantly MANA constructs for siRNA applications, especially with A, G and $\mathrm{U}$ analogs (Table 1). This experiment, as calculated at $37^{\circ} \mathrm{C}$, clearly showed a minimum increase of the thermodynamic affinity from $5 \%$ to $16 \%$ compared to the unmodified RNA strand. These results show quantitatively that a single incorporation stabilizes the antiparallel duplexes by 4.2 $\mathrm{kCal} . \mathrm{mol}^{-1}, 3.5 \mathrm{kCal}^{\mathrm{mol}}{ }^{-1}$ and $3.9 \mathrm{kCal}_{\mathrm{mol}}{ }^{-1}$ as an average for the four heterocyclic bases for respectively MANA, ANA and HNA constructs. These results are comparable or higher than those recently obtained with for example locked nucleic acids [38]. The large stabilization of RNA double strands is largely due to the decrease in $\Delta \mathrm{H}^{\circ}$ which is much more favorable than the loss in entropy factor, reflected by $\mathrm{T} \Delta \mathrm{S}^{\circ}$. The decrease in $\Delta \mathrm{H}^{\circ}$ is generally larger for MANA analogs. Methylation of the 3'-hydroxyl moiety of ANA building blocks affording MANA congeners thus yields a further stability increase as expected $\left(0.7 \mathrm{kCal} . \mathrm{mol}^{-1}\right)$ and as seen before in 2'-O-methylated RNA constructs [29]. It needs to be mentioned however, that when considering cytosine analogs this advantage is rather negligible when comparing HNA and MANA.

\section{Thermal analysis of multiple-modified oligonucleotides}


The affinity of double and fully modified ON constructs for complementary RNA sequences likewise was thermally evaluated and the results are shown in Table 2. In general, sequences containing modified synthons provided a better stability to the duplex compared to natural dsRNA upon insertion of a second modification in one of the strands. This way HNA and ANA modifications lead to an increase in stability of the HNA/RNA duplexes of, depending on the base moiety, between 0.6 and $2.5^{\circ} \mathrm{C}$ per modification and for the ANA/RNA duplexes between 0.7 and $2.8^{\circ} \mathrm{C}$ per modification, respectively. However, a pronounced larger increase in thermal stability can be noticed for MANA/RNA duplexes versus dsRNA duplexes. The increase mounted to +1.1 to $+3.5^{\circ} \mathrm{C}$ per incorporated monomer, clearly demonstrating the interest of methylation of the 3'-O-hydroxyl moiety of ANA. The alkylation clearly contributes to the stabilization of the duplex by a cooperative effect which might be amplified when using fully modified constructs.

For clarity, the extent of the increase in stability of hexitol constructs paired with RNA was largely dependent of the nature of the base and of the sequence used for the study. Indeed, we noticed a large difference between $\mathrm{A}$ and $\mathrm{U}$ monomers on the one hand, and $\mathrm{C}$ and $\mathrm{G}$ analogs on the other hand. Substitution of A or U monomers by the respective hexitol congeners (either HNA, ANA or MANA), induced an increase in thermal stability of $2.3^{\circ} \mathrm{C}$ to $3.5^{\circ} \mathrm{C}$ per modification, while substitution for $\mathrm{C}$ and $\mathrm{G}$ afforded only an increase of 0.6 to $1.5^{\circ} \mathrm{C}$ per modification. Fig. 5 displays thermal analysis for the ONs containing two uridine analogues.

Having established the comparative effect of single and multiple incorporation of either HNA, ANA or MANA analogs, we next wanted to evaluate and compare the stability of fully modified constructs. In view of the strong stabilization expected, a mixed octamer sequence was chosen. Indeed, each hexitol construct remarkably increased the thermal stability, with an average increase per modification of $1.4^{\circ} \mathrm{C}$ for the HNA construct, to even $2.4^{\circ} \mathrm{C}$ and $2.6^{\circ} \mathrm{C}$ for the ANA and MANA modification, respectively. The latter backbone thus afforded a $20.5^{\circ} \mathrm{C}$ rise in $\mathrm{Tm}$ for the fully modified octamer versus dsRNA. The smaller difference in stability as noted here for ANA versus MANA could be 
explained by the specific sequence used in this study. Indeed, only one A and one $U$ is found in the sequence under study. However, as previously shown in table 2, the difference in contribution to the stability of ANA or MANA modifications is relatively small for $\mathrm{G}$ and for $\mathrm{C}$ with less than $0.4^{\circ} \mathrm{C}$ difference, while for A and U monomers, the difference in thermal stability between the ANA and MANA backbone raises to $0.7^{\circ} \mathrm{C}$. Nevertheless, both the fully modified ANA and MANA constructs are clearly much more stabilizing the duplex with RNA. The strong affinity of MANA constructs for RNA therefore warrants the use of this backbone for antisense strategies. In addition, one has to note that for siRNA strategies, previous studies $[24,39]$ have demonstrated it to be preferable to modify the antisense strand at the 3' position rather than at the 5' position. The latter is due to the local thermodynamic instability required for selection of the correct guide strand in RISC. This means the introduction of MANA modifications specifically at the 3' position could further improve this required stability difference between terminal ends of siRNA double strands, highlighting the value of MANA congeners for siRNA studies as well.

\section{Evaluation of the specificity of modified double strands}

High affinity for the complementary target is of great importance in antisense and siRNA strategies. Nevertheless, to avoid side effects, the specificity of the ON constructs likewise is a great point of interest. These properties are rarely documented in other reports presenting new modifications for siRNA applications. We here have evaluated the discrimination potential of the new MANA modification and compare the results with those of ANA, HNA and RNA analogs. An evaluation of the whole series of $\Delta \mathrm{Tm}$ setween the matched dsRNA containing a single hexitol modification and the same double strand with a ribonucleoside mismatch base pair was realized and is presented in Fig. 6. Hereto, the thermal stability of the RNA sequence 5'-GCGU-X-UGCG-3' with for $\mathbf{X}$ any of the 
four HNA, ANA or MANA congeners, was determined versus any RNA (semi-)complementary sequence having either a match or mismatch base in the middle [r(CGCANACGC)].

From this large study, natural RNAs clearly appear to be the most specific synthons for discriminating versus mismatch base pairs. In general, the stability loss of the duplex as of the mismatch, is largest in case of RNA/RNA mismatches, with a few predictable exceptions ( $\mathrm{rU} / \mathrm{rG}$ and $\mathrm{rG} / \mathrm{rA}$ mismatches). In average on all experiments, the destabilization for RNA/RNA mismatches for these short duplexes mounted to $20.5^{\circ} \mathrm{C}$, while the average destabilization for HNA, ANA and MANA containing duplexes was slightly lower but similar and reached $17.6^{\circ} \mathrm{C}, 16.4^{\circ} \mathrm{C}$ and $16.5^{\circ} \mathrm{C}$, respectively. Hence, all hexitol constructs clearly discriminated for mismatches, albeit to a smaller extent when considering $\mathrm{U}^{*} / \mathrm{rU}$ and $\mathrm{G}^{*} / \mathrm{rU}$ mismatches (see Fig. 3). Within the HNA and ANA series this discriminative potential has been shown before [24], as for various antisense and siRNA applications, sequences with mismatches proved devoid of activity. Hence, the slightly lower selectivity profile of MANA constructs versus natural RNAs should not hamper their application in siRNA strategies.

\section{Conclusion}

A series of 3'-O-methylated D-altritol nucleic acids (MANA) comprising uracil, adenine, cytosine and guanine base moieties were prepared and studied. These hexitol nucleoside congeners were incorporated into RNA sequences to evaluate their effect on the stability of duplexes formed with complementary RNA strands. As shown before with hexitol nucleic acids (HNA) and altritol nucleic acids (ANA) incorporated in similar sequences, the MANA monomers induced an even more

pronounced stabilization of duplexes. The improved thermal affinity for RNA sequences in comparison to HNA and ANA analogs depends on the sequence used as well as the number of modifications introduced. Moreover, thermodynamics showed quantitatively that introduction of a MANA monomer stabilized the duplex by $4.2 \mathrm{kCal} \mathrm{mol}^{-1}$ on average for a single modification. This is similar but more pronounced than with HNA and ANA modifications which stabilize the duplex by 
3.9 and $3.5 \mathrm{kCal} . \mathrm{mol}^{-1}$, respectively. The large stabilization is obtained mainly by a more favorable enthalpic contribution. The impact of the MANA modification on the stabilization is clearly sequence dependent and can be optimized by judicious choice of the modification position. In particular, substitution of A and/or U monomers proved strongly advantageous. In addition, the retained ability of MANA constructs to discriminate for a mismatch base pair has been clearly demonstrated. While the specificity is slightly less compared to natural RNA synthons, it is similar to those of HNA and ANA analogs, strongly arguing in favor of the use of MANA constructs for both antisense and siRNA applications.

\section{Experimental section}

Materials and methods: The benzylidene-protected allitol epoxide (2) was obtained from Carbosynth (UK). All other chemicals were provided by Aldrich or ACROS and were of the highest quality. ${ }^{1} \mathrm{H}$ and ${ }^{13} \mathrm{C}$ NMR spectra were determined with a $300 \mathrm{MHz}$ Varian Gemini apparatus with tetramethylsilane as internal standard for the ${ }^{1} \mathrm{H}$ NMR spectra $(\mathrm{s}=$ singlet, $\mathrm{d}=$ doublet, $\mathrm{dd}=$ double doublet, $\mathrm{t}=$ triplet, br. $\mathrm{s}=$ broad signal, br. $\mathrm{d}$ = broad doublet, $\mathrm{m}=$ multiplet) and the solvent signal $\operatorname{DMSO}_{-} d_{6}(\delta=39.6 \mathrm{ppm})$, MeOD $(\delta=49.3 \mathrm{ppm})$ or $\mathrm{CDCl}_{3}(\delta=76.9 \mathrm{ppm})-$ for the ${ }^{13} \mathrm{C}$ NMR spectra. For some products a Varian Unity-500 spectrometer (500 MHz for ${ }^{1} \mathrm{H}$ NMR) was used. Coupling constant values were derived by first-order spectral analysis. Exact mass measurements were performed with a quadrupole/orthogonal acceleration time-of-flight tandem mass spectrometer (qTOF2, Micromass, Manchester, UK) fitted with a standard electrospray ionization interface. Oligonucleotide spectra were acquired on a quadrupole orthogonal acceleration time-of-flight mass spectrometer (Synapt G2 HDMS, Waters, Milford, MA). Samples were infused at $3 \mu \mathrm{L} / \mathrm{min}$ and spectra were obtained in positive (or: negative) ionization mode with a resolution of 15000 (FWHM) using leucine enkephalin as lock mass. Synthesis of HNA and ANA monomers was outlined before 
[10,30]. Assembly of ANA and HNA constructs likewise has been described previously [11,12]. Synthesis of the maU block has been documented before [27] but an improved procedure is given in this account.

1',5'-Anhydro-4',6'-O-benzylidene-3'-O-methyl-2'-deoxy-2'-(uracil-1-yl)-D-altro-hexitol

[27]: The altritol derivative $\underline{\text { 3a }}$ [30] (3.7 g, $10.7 \mathrm{mmol})$ was dried overnight under vacuum. The foam was dissolved in dry THF $(148 \mathrm{~mL})$, cooled to $0^{\circ} \mathrm{C}$ and $\mathrm{NaH}(1.3 \mathrm{~g}, 32 \mathrm{mmol})$ was added and the mixture was stirred at $0^{\circ} \mathrm{C}$ for $1 \mathrm{~h}$ under argon. Subsequently, methyl iodide $(1 \mathrm{~mL}, 16 \mathrm{mmol})$ was dissolved in dry THF (15 mL) and the solution was added drop wise over 30 min to the reaction mixture at $0^{\circ} \mathrm{C}$. The yellow solution was stirred at $0^{\circ} \mathrm{C}$ for an additional $2 \mathrm{~h}$ before adding an extra amount of methyl iodide ( $1 \mathrm{~mL}, 16 \mathrm{mmol}$ in $11 \mathrm{~mL}$ dry THF). The reaction was left stirring for $2 \mathrm{~h}$ more at $0^{\circ} \mathrm{C}$ when adding a last amount of $\mathrm{MeI}(660 \mu \mathrm{L}, 10 \mathrm{mmol}$ in $10 \mathrm{~mL} \mathrm{THF})$. The reaction was finally running $1 \mathrm{~h}$ more at $0^{\circ} \mathrm{C}$ before quenching with $12 \mathrm{~mL} \mathrm{MeOH}$ for $20 \mathrm{~min}$. The solution was concentrated and dissolved in ethyl acetate $(150 \mathrm{~mL})$ and washed with saturated aqueous $\mathrm{NaHCO}_{3}$ $(150 \mathrm{~mL})$. The aqueous layer was extracted with ethyl acetate $(150 \mathrm{~mL})$ and DCM $(150 \mathrm{~mL})$. Combined organic layers were dried $\left(\mathrm{Na}_{2} \mathrm{SO}_{4}\right)$, filtered off and concentrated. Purification by silica column chromatography (0-4\% MeOH/dichloromethane) afforded the methylated nucleoside $\underline{\mathbf{4 a}}$ [1987 mg, $5.5 \mathrm{mmol}$, 52\% yield] as a yellow foam while recovering the starting nucleoside $\underline{\mathbf{3 a}}$ [1700 mg, 4.9 mmol, $46 \%$ yield].

${ }^{1} \mathrm{H}\left(\mathrm{CDCl}_{3}, 300 \mathrm{MHz}\right): \delta 3.65$ ppm(s, 3H, O-Me); 3.67-4.40 (m, 7H, 4'-H, 6'-Ha, 5'-H, 1'-Ha, 1'-He, 6'-He and 3'-H); 4.54 (m, 1H, 2'-H); 5.55 (s, 1H, Ph-Cㅌ); 5.81 (d, 1H, J= 8.0Hz, 5-H); 7.36-7.50 (m, 5H, ar-H); 8.05 (d, 2H, J=8.2Hz, 6-H); 9.14 (br s, $1 \mathrm{H}, \mathrm{NH}) .{ }^{13} \mathrm{C}\left(\mathrm{CDCl}_{3}, 75 \mathrm{MHz}\right): \delta 55.0 \mathrm{ppm}(\mathrm{C} 2$ '); 59.8 (O-CH$\left.{ }_{3}\right) ; 64.4$ (C1’); 66.8 (C6’); 69.1 (C5’); 74.9 (C4’); 77.3 (C3’); 102.5 (C5); 102.8 (Ph-CE); 126.3 (Co Ph); 128.4 (Cm Ph); 129.3 (Cp Ph); 137.2 (Cq Ph); 142.3 (C6); 150.9 (C2); 163.1 (C4). HRMS (thgly) calcd. for $\mathrm{C}_{18} \mathrm{H}_{20} \mathrm{~N}_{2} \mathrm{O}_{6} \mathrm{Na}^{+}\left(\mathrm{M}+\mathrm{Na}^{+}\right)$383.1219, found 383.1229. 
1',5'-Anhydro-3'-O-methyl-2'-deoxy-2'-(uracil -1-yl)-D-altro-hexitol (ㅁa): The previous product 4a $(1.7 \mathrm{~g}, 4.7 \mathrm{mmol})$ was dried overnight under vacuum and was dissolved in dry DCM $(25 \mathrm{~mL})$ and cooled to $0^{\circ} \mathrm{C}$. TFA $(2.1 \mathrm{~mL}, 28.8 \mathrm{mmol})$ was added at $0^{\circ} \mathrm{C}$ and the mixture was stirred for $90 \mathrm{~min}$. Water (96 $\mu \mathrm{L}, 5.3 \mathrm{mmol}$ ) was added at $0^{\circ} \mathrm{C}$ and the solution was stirred for $20 \mathrm{~min}$. Finally, pyridine was added and the solution was stirred at $0^{\circ} \mathrm{C}$ for $3 \mathrm{~h}$ until complete precipitation. The white crystal was filtered off using a glass filter, washed with cold DCM $(2 \times 1.5 \mathrm{~mL})$ and dried under vacuum in a desiccator. The desired nucleoside $\underline{\mathbf{6 a}}$ [960 mg, $3.5 \mathrm{mmol}$, 75\% yield] was afforded as a white solid. ${ }^{1} \mathrm{H}$ (MeOD, 300MHz): $\delta 3.60$ ppm (s, 3H, O-Me); 3.66-4.13 (m, 7H, 4'-H, 6'-Ha, 5'-H, 1'-Ha, 1'-He, 6'-He and 3'-H); 4.62 (m, 1H, 2'-H); 5.66 (d, 1H, J=7.7Hz, 5-H); 8.08 (d, 1H, J=7.7Hz, 5-H).

${ }^{13} \mathrm{C}$ (DMSO- $\left.d_{6}, 75 \mathrm{MHz}\right): \delta 52.7$ ppm (C2'); $54.9\left({\left.\mathrm{O}-\mathrm{CH}_{3}\right) ;}^{2} 7.5\right.$ (C6’); 60.1 (C4'); 63.0 (C1'); 77.1 (C5’); 77.9 (C3’); 101.2 (C5); 143.1 (C6); 151.3 (C2); 163.6 (C4). HRMS (thgly) calcd. for $\mathrm{C}_{11} \mathrm{H}_{15} \mathrm{~N}_{2} \mathrm{O}_{6} \mathrm{Na}_{2}{ }^{+}\left(\mathrm{M}+2 \mathrm{Na}^{+}\right)$317.0726, found 317.0723.

\section{1',5'-Anhydro-4',6'-O-benzylidene-3'-O-methyl-2'-deoxy-2'-(cytosin-1-yl)-D-altro-hexitol (4b):}

1,2,4-1H-triazole (3.2 g, $46.8 \mathrm{mmol}$ ) was dried $2 \mathrm{~h}$ under vacuum in a desiccator. A solution of triazole and phosphorus oxychloride $(0.9 \mathrm{~mL}, 9.9 \mathrm{mmol})$ was prepared in pyridine $(25 \mathrm{~mL})$ at $0^{\circ} \mathrm{C}$. Triethylamine $(6.2 \mathrm{~mL}, 44.8 \mathrm{mmol})$ was added dropwise at $0^{\circ} \mathrm{C}$ and the solution was stirred $30 \mathrm{~min}$. The uracil derivative $\underline{\mathbf{4 a}}$ dissolved in dry pyridine $(25 \mathrm{~mL})$ was added at $0^{\circ} \mathrm{C}$ and the solution was stirred for $2 \mathrm{~h}$ at room temperature (RT) and concentrated and coevaporated with toluene $(2 \times 20 \mathrm{~mL})$. The crude product was dissolved with DCM $(150 \mathrm{~mL})$ and washed twice with brine $(60 \mathrm{~mL})$. The aqueous layer was extracted with DCM $(30 \mathrm{~mL})$. Combined organic layers were dried $\left(\mathrm{Na}_{2} \mathrm{SO}_{4}\right)$, filtered off and evaporated. The residue was dissolved in dioxane $(110 \mathrm{~mL})$, cooled to $0^{\circ} \mathrm{C}$ and aqueous ammonia 25\% (40 mL) were added. The solution was left overnight at RT. The solution was 
evaporated and coevaporated with toluene $(3 \times 50 \mathrm{~mL})$. The residue was dissolved in 50:50 $\mathrm{DCM} / \mathrm{MeOH}$ and evaporated with silica. Purification by silica column chromatography (2-5\% $\mathrm{MeOH} /$ dichloromethane) afforded the methylated cytidine analog $\underline{\mathbf{4 b}}$ [1606 mg, $4.5 \mathrm{mmol}, 87 \%$ yield] as a white foam.

${ }^{1} \mathrm{H}\left(\mathrm{CDCl}_{3}, 300 \mathrm{MHz}\right): \delta 3.65$ ppm (m, 5H, 5'-H, O-Me and 3'-H); 3.96-4.36 (m, 5H, 4'-H, 6'-Ha, 1'Ha, 1'-He and 6'-He); 4.66 (m, 1H, 2'-H); 5.51 (s, 1H, Ph-Cㅡ); 5.81 (d, 1H, J=7.2Hz, 5-H); 7.34-7.45 (m, 5H, ar-H); 8.09 (d, 1H, 6-H); 8.18 (br s, $\left.2 \mathrm{H}, \mathrm{NH}_{2}\right) .{ }^{13} \mathrm{C}\left(\mathrm{CDCl}_{3}, 75 \mathrm{MHz}\right): \delta 55.4$ ppm (C2'); 59.5 (O-CH 3 ); 64.8 (C1’); 66.8 (C5’); 69.2 (C6’); 74.7 (C4’); 77.3 (C3’); 95.0 (C5); 102.5 (Ph-C); 126.3 (Ar-Co); 128.4 (Ar-Cm); 129.2 (Ar-Cp); 137.3 (Ar-Ci); 143.8 (C6); 157.0 (C2); 165.7 (C4). HRMS (thgly) calcd. for $\mathrm{C}_{18} \mathrm{H}_{22} \mathrm{~N}_{3} \mathrm{O}_{5}{ }^{+}\left[\mathrm{M}+\mathrm{H}^{+}\right] 360.1554$, found 360.1562

\section{1',5'-Anhydro-4',6'-O-benzylidene-3'-O-methyl-2'-deoxy-2'-( $N^{6}$-benzoylcytosin-1-yl)-D-altro-}

hexitol ( $\underline{\mathbf{5 b}})$ : The analog $\underline{\mathbf{4 b}}$ (1606 mg, $4.5 \mathrm{mmol})$ was coevaporated with dry pyridine $(6 \mathrm{~mL})$, dissolved in dry pyridine $(20 \mathrm{~mL})$ and cooled at $0^{\circ} \mathrm{C}$. Benzoyl chloride $(1.6 \mathrm{~mL}, 13.4 \mathrm{mmol})$ was added and the solution was allowed to come to RT. The solution was stirred $16 \mathrm{~h}$ at RT. The brown solution was cooled to $0^{\circ} \mathrm{C}$ and water $(1 \mathrm{~mL})$ was added. Then, aqueous ammonia $25 \%(10 \mathrm{~mL})$ was added and the solution was stirred $1 \mathrm{~h}$ at RT. The volatiles were removed under reduced pressure and coevaporated, each time with toluene ( $3 \times 15 \mathrm{~mL})$. The residue was adsorbed on silica by coevaporation and purified by silica column chromatography (2-6\% MeOH/DCM) affording the protected nucleoside $\underline{\mathbf{5 b}}$ [1710 mg, $3.7 \mathrm{mmol}, 82 \%$ yield] as a white foam.

${ }^{1} \mathrm{H}\left(\mathrm{CDCl}_{3}, 300 \mathrm{MHz}\right): \delta$ 3.62-3.75 ppm (m, 5H, O-Me, 5'-H and 3'-H); 4.02-4.43 (m, 5H, 4'-H, 6'Ha, 1'-Ha, 1'-He and 6'-He); 4.75 (m, 1H, 2'-H); 5.52 (s, 1H, Ph-Cㅌ); 7.34-7.44 (m, 5H, ar-H); 7.527.57 (m, 3H, H-bz); 7.75 (d, 1H, J= 7.4Hz, 5-H); 8.07 (d, 2H, H-Bz); 8.48 (d,1H, J= 7.4Hz, 6-H). ${ }^{13} \mathrm{C}$ (CDCl 3 , 75MHz): $\delta 56.3$ ppm (C2’); 59.7 (O-Me); 64.7 (C1’); 66.9 (C5’); 69.2 (C6’); 74.2 (C4'); 77.0 
(C3’); 97.7 (C5); 102.5 (Ph-C); 126.3, 127.5, 128.4, 128.4, 129.3, 132.3, 137.3, 147.4 (aryl-C); 163.2

(C2); 171.1 (C4). HRMS (thgly) calcd. for $\mathrm{C}_{25} \mathrm{H}_{26} \mathrm{~N}_{3} \mathrm{O}_{6}{ }^{+}\left[\mathrm{M}+\mathrm{H}^{+}\right]$464.1816, found 464.1821.

1',5'-Anhydro-3'-O-methyl-2'-deoxy-2'-(N+6enzoylcytosin-1-yl)-D-altro-hexitol $\quad(\underline{6 b}): \quad$ The cytidine analog $\underline{\mathbf{5 b}}$ (1710 mg, $3.7 \mathrm{mmol}$ ) was dried under vacuum for $2 \mathrm{~h}$ and was dissolved in dry DCM $(15 \mathrm{~mL})$ and cooled to $0^{\circ} \mathrm{C}$. TFA $(2 \mathrm{~mL}, 26.8 \mathrm{mmol})$ was then added at $0^{\circ} \mathrm{C}$ and stirred for 90 min. Water $(89 \mu \mathrm{L}, 5 \mathrm{mmol})$ was added at $0^{\circ} \mathrm{C}$ and the solution was stirred for 20 min. Finally, pyridine $(2.4 \mathrm{~mL}, 29.8 \mathrm{mmol})$ was added and the solution was stirred at $0^{\circ} \mathrm{C}$ for $3 \mathrm{~h}$ until completed precipitation. The white crystal was filtered off using a glass filter, washed with cold DCM (2x2 mL) and dry under vacuum in a desiccator. The desired nucleoside $\underline{\mathbf{6 b}}$ [1042 mg, $2.8 \mathrm{mmol}$, 75\% yield] was isolated as a white solid.

${ }^{1} \mathrm{H}$ (MeOD, 300MHz): $\delta$ 3.59-3.85 ppm (m, 8H, O-Me, 5'-H; 3'-H; 4'-H, 6'-Ha and 6'-He); 4.19 (d, 2H, $J=2,2 \mathrm{~Hz}, 1^{\prime}-\mathrm{Ha}$ and 1'-He); 4.73 (m, 1H, 2'-H); 7.52-7.57 (m, 3H, H-bz); 7.63 (d, 1H, $J=7.4 \mathrm{~Hz}$, 5-H); 7.98 (d, 2H, H-Bz); 8.68 (d,1H, $J=7.4 \mathrm{~Hz}, 6-\mathrm{H}) .{ }^{13} \mathrm{C}$ (MeOD, 75MHz): $\delta 56.5$ ppm (C2'); 59.0 (O-Me); 62.3 (C6’); 64.6 (C1’); 65.0 (C4’); 78.2 (C5’); 78.5 (C3’); 98.7 (C5); 129.1, 129.8, 134.1, 149.5 (aryl-C); 164.6 (C2); 172.6 (C4). HRMS (thgly) calcd. for $\mathrm{C}_{18} \mathrm{H}_{22} \mathrm{~N}_{3} \mathrm{O}_{6}{ }^{+}\left[\mathrm{M}+\mathrm{H}^{+}\right]$376.1503, found 376.1508

Synthesis of 1',5'-Anhydro-4',6'-O-benzylidene-3'-O-methyl-2'-deoxy-2'-(adenin-9-yl)- $D$-altrohexitol (4c): The analog $\underline{3 c}$ [30] (2.4 g, $6.5 \mathrm{mmol})$ was coevaporated with dry DMF (3x12 mL). The foam was dissolved in dry DMF (35 mL) and cooled to $-20^{\circ} \mathrm{C}$. NaH (340 mg, $8.5 \mathrm{mmol}$ ) was added and the mixture was stirred at $-20^{\circ} \mathrm{C}$ for $1 \mathrm{~h}$ under argon. Methyl iodide $(0.49 \mathrm{~mL}, 7.8 \mathrm{mmol})$ was dissolved in dry DCM (4 mL) and the solution was added drop wise over $30 \mathrm{~min}$ to the NaH mixture at $-20^{\circ} \mathrm{C}$. The yellow solution was stirred at $-20^{\circ} \mathrm{C}$ for an additional $3 \mathrm{~h}$ before quenching of the reaction with $\mathrm{MeOH}$ (3 mL). The pale yellow solution was warmed to RT and concentrated to dryness under vacuum. The residue was dissolved in ethyl acetate $(60 \mathrm{~mL})$ and washed with aqueous saturated 
$\mathrm{NaHCO}_{3}(20 \mathrm{~mL})$. The organic layer was then washed with brine $(30 \mathrm{~mL})$, and the combined aqueous layers were extracted with ethyl acetate $(40 \mathrm{~mL})$. The combined organic layers were dried $\left(\mathrm{Na}_{2} \mathrm{SO}_{4}\right)$, filtered and concentrated. Purification by silica column chromatography (0-3\% MeOH/DCM) afforded the methylated nucleoside $\underline{\mathbf{4 c}}$ [1036 mg, $2.7 \mathrm{mmol}$, 41\% yield] as a yellow foam while part of the starting material $\underline{3 c}$ was recovered [467 mg, $1.3 \mathrm{mmol}$, 19\% yield].

${ }^{1} \mathrm{H}$ (DMSO-d 6 , 300MHz): $\delta 3.58$ ppm (s, 3H, O-CH $)$; 3.73-4.36 (m, 7H, 6'-Ha, 4'-H, 5'-H, 1'-Ha, 6'He, 1'-He and 3'-H); 4.77 (m, 1H, 2'-H); 5.61 (s, 1H, Ph-Cㅌ); 7.34 (m, 5H, ar-H); 8.20 (s, 1H, 2-H); 8.24 (s, 1H, 8-H). ${ }^{13} \mathrm{C}$ (DMSO-d,, $\left.75 \mathrm{MHz}\right): \delta 52.7$ ppm (C2’); 58.9 (C6’); 64.6 (C4'); 66.9 (C1'); 68.1 (C3’); $74.8\left(\mathrm{O}-\mathrm{CH}_{3}\right) ; 76.0$ (C5’); 101.1 (Ph-ㅡㅐ); 118.3 (C5); 126.1, 126.3, 127.9, 128.0, 128.8, 137.6 (aryl-C); 138.9 (C8); 149.5 (C4); 152.8 (C2); 156.1 (C6). HRMS (thgly) calcd. for $\mathrm{C}_{19} \mathrm{H}_{22} \mathrm{~N}_{5} \mathrm{O}_{4}{ }^{+}$ $\left[\mathrm{M}+\mathrm{H}^{+}\right]$384.1666, found 384.1677.

\section{1',5'-Anhydro-4',6'-O-benzylidene-3'-O-methyl-2'-deoxy-2'-( $N^{6}$-benzoyladenin-9-yl)-D-altro-}

hexitol (두): The adenosine analog $\underline{4 \mathbf{c}}(1.3 \mathrm{~g}, 3.4 \mathrm{mmol})$ was dissolved in dry pyridine $(18 \mathrm{~mL})$ and cooled to $0^{\circ} \mathrm{C}$. Benzoyl chloride $(2.2 \mathrm{~mL}, 18.7 \mathrm{mmol})$ was added and the solution was allowed to come to RT and was stirred overnight. The brown solution was cooled again to $0^{\circ} \mathrm{C}$ and water $(1 \mathrm{~mL})$ was added. After 5 minutes, aqueous $25 \% \mathrm{NH}_{3}(3.5 \mathrm{~mL})$ was added and the mixture was stirred $1 \mathrm{~h}$ at $0^{\circ} \mathrm{C}$. Volatiles were removed under reduced pressure and coevaporated several times with toluene (3x20 mL). The resulting mixture was dissolved in DCM $(20 \mathrm{~mL})$ and filtered off using a glass filter. The solid was washed with DCM $(2 \times 10 \mathrm{~mL})$. Mother liquids were coevaporated with silica gel and purification by silica column chromatography (10-0\% hexane/ethyl acetate) afforded the protected nucleoside $\underline{\mathbf{5 c}}$ [1187 mg, $2.4 \mathrm{mmol}, 72 \%$ yield] as a white solid.

${ }^{1} \mathrm{H}$ (DMSO-d $\left.d_{6}, 300 \mathrm{MHz}\right): \delta 3.62$ ppm (s, 3H, O-Me); 3.77-4.44 (m, 7H, 4'-H, 6'-Ha, 5'-H, 1'-Ha, 1'He, 6'-He and 3'-H); 4.94 (m, 1H, 5'-H); 5.62 (s, 1H, Ph-Cㅌ); 7.35 (m, 5H, ar-H); 7.49-7.68 (m, 3H, H-bz); 8.05 (d, 2H, H-Bz); 8.56 (s, 1H, 2-H); 8.80 (s,1H, 8-H); 11.23 (br s, 1H, NH). ${ }^{13} \mathrm{C}$ (DMSO-d 
75MHz): $\delta 53.0$ ppm (C2’); 58.9 (C6’); 64.5 (C4’); 66.9 (C1’); 68.1 (C3’); 74.8 (O-CH3); 76.0 (C5’); 101.2 (Ph-ㅡ); 125.9 (C5); 126.1, 128.0, 128.5, 128.8, 132.4, 132.8, 137.6 (aryl-C); 142.7 (C8); 150.4 (C4); 151.7 (C2); 156.3 (C6); 167.3 (C=O). HRMS (thgly) calcd. for $\mathrm{C}_{26} \mathrm{H}_{26} \mathrm{~N}_{5} \mathrm{O}_{5}{ }^{+}\left[\mathrm{M}+\mathrm{H}^{+}\right] 488.1928$, found 488.1935 .

1',5'-Anhydro-3'-O-methyl-2'-deoxy-2'-( $N^{6}$-benzoyladenin-9-yl)-D-altro-hexitol $\quad$ (6c): The previous obtained product $\underline{\mathbf{5 c}}$ (1187 mg, $2.4 \mathrm{mmol})$ was dried overnight under vacuum, dissolved in dry DCM (3.7 mL) and cooled to $0^{\circ} \mathrm{C}$. TFA (6.25 eq., $\left.1.1 \mathrm{~mL}\right)$ was then added at $0^{\circ} \mathrm{C}$ and stirred for $30 \mathrm{~min}$. Water (1.5 eq., $65 \mu \mathrm{L}$ ) was added at $0^{\circ} \mathrm{C}$ and the solution was stirred for 20 min. Finally, pyridine (6.5 eq., $1.3 \mathrm{~mL}$ ) was added and the solution was stirred at $0^{\circ} \mathrm{C}$ for $3 \mathrm{~h}$ until complete precipitation. The white crystal was filtered off using a glass filter, washed with cold DCM (2x1.5 $\mathrm{mL}$ ) and dry under vacuum in a desiccator. The desired nucleoside $\underline{\mathbf{6 d}}$ [776 mg, $1.9 \mathrm{mmol}, \mathbf{8 1} \%$ yield] was isolated as a white solid.

${ }^{1} \mathrm{H}$ (MeOD, 300MHz): $\delta$ 3.61-3.94 ppm (m, 10H, O-Me, 4'-H, 6'-Ha, 5'-H, 1'-Ha, 1'-He, 6'-He and 3’-H); 5.01 (m, 1H, 2'-H); 7.50-7.68 (m, 3H, H-bz ${ }_{m+p}$ ); 8.11 (d, 2H, H-Bzo); 8.73 (s, 1H, 2-H); 8.75 (s, 1H, 8-H). ${ }^{13} \mathrm{C}\left(\mathrm{CDCl}_{3}, 75 \mathrm{MHz}\right): \delta 52.4$ ppm (C2'); 59.0 (O-Me); 61.4 (C6'); 63.6 (C4'); 64.1 (C1'); 77.4 (C3’); 77.5 (C5’); 121.4 (C5); 128.1, 128.7, 132.9, 133.0 (aryl-C); 148.2 (C8); 149.1 (C6); 151.9 (C2); 152.1 (C4); 165.9 (C=O). HRMS (thgly) calcd. for $\mathrm{C}_{19} \mathrm{H}_{22} \mathrm{~N}_{5} \mathrm{O}_{5}{ }^{+}\left[\mathrm{M}+\mathrm{H}^{+}\right] 400.1615$, found 400.1614

1',5'-Anhydro-4',6'-O-benzylidene-2'-deoxy-3'-O-methoxy-(2-amino-6-chloropurin-9-yl)-D-

altro-hexitol (4e): The 6-chloropurine analog $\underline{\mathbf{3 e}}$ [30] (3.5 g, $8.6 \mathrm{mmol})$ was dried under vacuum overnight, followed by coevaporation with dry DMF (2x12 mL). The foam was dissolved in dry DMF (50mL) and cooled to $-30^{\circ} \mathrm{C}$. $\mathrm{NaH}(0.4 \mathrm{~g}, 10.4 \mathrm{mmol})$ was added and the mixture was stirred at $-30^{\circ} \mathrm{C}$ for $1 \mathrm{~h}$ under argon. Methyl iodide $(0.65 \mathrm{~mL}, 10.4 \mathrm{mmol})$ dissolved in dry DCM (5 mL) was added 
drop wise over 50 min to the $\mathrm{NaH}$ mixture at $-30^{\circ} \mathrm{C}$. The yellow solution was stirred at $-30^{\circ} \mathrm{C}$ for an additional $2 \mathrm{~h} 30$ before quenching of the reaction with $\mathrm{MeOH}(3 \mathrm{~mL})$. The pale yellow solution was warmed to RT and concentrated to dryness under vacuum. The crude product was dissolved in a mixture of water $(40 \mathrm{~mL})$ and DCM $(50 \mathrm{~mL})$. The aqueous layer was extracted with DCM (2x50 mL) and the combined organic layers were washed with water $(20 \mathrm{~mL})$. The organic layer was dried $\left(\mathrm{Na}_{2} \mathrm{SO}_{4}\right)$, filtered off and concentrated to dryness. Purification by silica column chromatography (02\% MeOH/dichloromethane) afforded the 3'-O-methylated nucleoside analog $\underline{4 e}$ [2.2 g, $5.2 \mathrm{mmol}$, $61 \%$ yield] as yellow foam.

${ }^{1} \mathrm{H}$ (DMSO-d $\left.\mathrm{D}_{6}, 300 \mathrm{MHz}\right): \delta 3.60$ ppm (s, 3H, 3'-OMe); 3.73-4.31 (m, 7H, 6'-Ha, 4'-H, 1'-Ha, 3'-H,

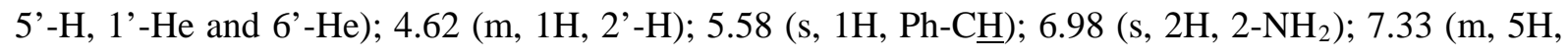
ar-H); 8.19 (s, $1 \mathrm{H}, 8-\mathrm{H}) .{ }^{13} \mathrm{C}$ (DMSO-d 6 , 75MHz): $\delta 54.0$ ppm (C2’); 59.3 (OMe); 65.2 (C1'); 67.8 (C5’); 68.9 (C6’); 75.2 (C3’); 77.0 (C4’); 102.0 (Ph-C); 123.8 (C5); 127.0, 129.0, 129.7, 138.6 (arylC); 142.0 (C8); 150.5 (C2); 155.0 (C4); 160.8 (C6). HRMS (thgly) calcd. for $\mathrm{C}_{19} \mathrm{H}_{21} \mathrm{ClN}_{5} \mathrm{O}_{4}{ }^{+}\left[\mathrm{M}+\mathrm{H}^{+}\right]$ 418.1277, found 418.1280.

1',5'-Anhydro-4',6'-O-benzylidene-2'-deoxy-3'-O-methyl-(guanin-9-yl)-D-altro-hexitol

(4d):

DABCO (234 mg, $2 \mathrm{mmol})$ and the product $\underline{4 e}(2729 \mathrm{mg}, 6.5 \mathrm{mmol})$ were added to a solution of $\mathrm{NaOH}$ in water $(1 \mathrm{M}, 25 \mathrm{~mL})$. The mixture was stirred $5 \mathrm{~h}$ at $90^{\circ} \mathrm{C}$ and was then cooled to $0^{\circ} \mathrm{C}$. The $\mathrm{pH}$ was adjusted to neutral with $\mathrm{HCl}(1 \mathrm{~N}, 20 \mathrm{~mL})$ at $0^{\circ} \mathrm{C}$.The solution was filtered off using a glass filter and the solid was washed with cold water $(3 \times 20 \mathrm{~mL})$. The solid was then dried in a desiccator under vacuum for $2 \mathrm{~h}$ at. The desired nucleoside $\underline{\mathbf{4 d}}$ [2582 $\mathrm{mg}, 6.5 \mathrm{mmol}, 99 \%$ yield] was obtained as a white solid and was used without further purification for the next step.

${ }^{1} \mathrm{H}$ (DMSO-d $\left.d_{6}, 300 \mathrm{MHz}\right): \delta 3.56$ ppm (s, 3H, OMe); 3.77-4.20 (m, 7H, 4'-H, 6'-Ha, 5'-H, 1'-Ha, 1'He, 6'-He and 3'-H); 4.51 (br s, 1H, 2'-H); 5.62 (s, 1H, Ph-Cㅡ); 6.53 (br s, 2H, 2-NH ); $^{2} .36$ (m, 5H, ar-H); 7.85 (s, 1H, 8-H); 10.69 (br s, 1H, NH). ${ }^{13} \mathrm{C}$ (DMSO-d ${ }^{6}, 75 \mathrm{MHz}$ ): 53.6 ppm (C2'); 59.8 (C3’); 
65.5(C1'); 67.7 (C5’); 69.0 (C6’); 75.8 (O-Me); 77.0 (C4'); 102.0 (Ph-C); 116.9 (C5); 127.0, 129.0, 129.7, 136.4 (Ph); 138.6 (C8); 152.2 (C2); 154.7 (C4); 157.7 (C6). HRMS (thgly) calcd. for $\mathrm{C}_{19} \mathrm{H}_{22} \mathrm{~N}_{5} \mathrm{O}_{5}{ }^{+}\left[\mathrm{M}+\mathrm{H}^{+}\right]$400.1615, found 400.1609.

\section{1',5'-Anhydro-4',6'-O-benzylidene-2'-deoxy-3'-O-methyl-( $N^{2}$-(dimethylamino)methylene-}

guanin-9-yl)-D-altro-hexitol ( $\underline{\mathbf{5 d}})$ : The product $\underline{\mathbf{4 d}}$ (2.6 g, $5.6 \mathrm{mmol})$ was coevaporated with dry DMF (2x20 mL), dissolved in dry DMF (32 mL) and dimethylformamide diethyl acetal (4.5 mL, 26.1 mmol) was added. The solution was stirred overnight at RT. The green solution was cooled to $0^{\circ} \mathrm{C}$ and the reaction was quenched with water $(3 \mathrm{~mL})$. The solution was concentrated under vacuum and coevaporated with toluene $(2 \times 30 \mathrm{~mL})$. Purification by silica column chromatography $(2-5 \%$ $\mathrm{MeOH} / \mathrm{DCM}$ ) afforded the desired protected nucleoside $\underline{\mathbf{5 d}}$ [2546 mg, $5.6 \mathrm{mmol}, 98 \%$ yield] as a white solid.

${ }^{1} \mathrm{H}$ (DMSO-d $d_{6}, 300 \mathrm{MHz}$ ): $\delta 3.03$ and 3.12 ppm (two s, 6H, NMe $)$ ); 3.59 (s, 3H, OMe); 3.70-4.32 (m, 7H, 4'-H, 6'-Ha, 5'-H, 1'-Ha, 1'-He, 6'-He and 3'-H); 4.65 (br s, 1H, 2'-H); 5.61 (s, 1H, Ph-Cㅡ); 7.35 (m, 5H, ar-H); 7.91 (s, 1H, 8-H); 8.57 (s, 1H, N=Cㅌ); 11.35 (br s, 1H, NH). ${ }^{13} \mathrm{C}\left(\mathrm{DMSO}^{-} \mathrm{d}_{6}, 75 \mathrm{MHz}\right)$ : 34.6 and 40.8 ppm ( $\mathrm{NMe}_{2}$ ); 52.2 (C2’); 58.5 (C3’); 64.4(C1’); 66.8 (C5’); 68.1 (C6’); 74.9 (O-Me); 75.8 (C4'); 101.0 (Ph-C); 119.1 (C5); 126.1, 128.0, 128.8, 136.5 (aryl-C); 137.7 (C8); 149.9 (C4); 157.4 (C6); $157.7(\underline{\mathrm{C}}=\mathrm{N}) ; 158.1$ (C2). HRMS (thgly) calcd. for $\mathrm{C}_{22} \mathrm{H}_{27} \mathrm{~N}_{6} \mathrm{O}_{5}{ }^{+}\left[\mathrm{M}+\mathrm{H}^{+}\right]$455.2037, found 455.2044 .

\section{1',5'-Anhydro-2'-deoxy-3'-O-methyl-( $N^{2}$-(dimethylamino)methylene-guanin-9-yl)- $D$-altro-}

hexitol (며): The compound $\underline{\mathbf{5 d}}$ (2.5 g, $5.5 \mathrm{mmol})$ was dried overnight under vacuum, dissolved in dry DCM $(8.5 \mathrm{~mL})$ and cooled to $0^{\circ} \mathrm{C}$. TFA $(6.25$ eq., $2.6 \mathrm{~mL})$ was then added at $0^{\circ} \mathrm{C}$ and stirred for 30 min., after which water (1.5 eq., $0.15 \mathrm{~mL}$ ) was added and the solution was stirred further for $20 \mathrm{~min}$. Finally, pyridine (6.5 eq., $2.9 \mathrm{~mL}$ ) was added and the solution was stirred at $0^{\circ} \mathrm{C}$ for $3 \mathrm{~h}$ until complete precipitation. The white crystal was filtered off, washed with cold DCM (2x3 mL) and dried under 
vacuum in a desiccator. The desired nucleoside $\underline{\mathbf{6 d}}$ [1686 mg, $4.6 \mathrm{mmol}, 83 \%$ yield] was obtained as a white solid.

${ }^{1} \mathrm{H}$ (DMSO- $\left.d_{6}, 300 \mathrm{MHz}\right): \delta 3.04$ and 3.14 ppm (two s, 6H, NMe $)$ ); 3.46 (s, 3H, OMe); 3.58-4.07 (m, 7H, 4'-H, 6'-Ha, 5'-H, 3'-H, 1'-Ha, 1'-He and 6'-He); 4.63 (br s, 1H, 2'-H); 6.98 (s, 1H, 6'-OH); 7.32 (s, 1H, 4'-OH); 8.02 (s, 1H, 8-H); 8.58 (s, 1H, =Cㅌ); 11.33 (br s, $1 \mathrm{H}, \mathrm{NH}) .{ }^{13} \mathrm{C}\left(\mathrm{DMSO}-d_{6}, 75 \mathrm{MHz}\right)$ : 34.7 and 40.8 ppm (NMe $)$ ); 51.7 (C2'); 57.8 (O-Me); 60.0 (C6'); 63.2 (C1'); 63.5 (C4'); 77.6 (C3’); 78.0 (C5’); 118.8 (C5); 137.3 (C8); 149.9 (C4); 157.1 (C2); 157.6 ( $\underline{C}=\mathrm{N}) ; 162.3$ (C6). HRMS (thgly) calcd. for $\mathrm{C}_{15} \mathrm{H}_{21} \mathrm{~N}_{6} \mathrm{O}_{5}{ }^{-}\left[\mathrm{M}^{-}\right]$365.1579, found 365.1585. 
General procedure for nucleoside dimethoxytritylation and for phosphitylation: Both general procedures are analogous to those described in d'Alonzo et al [14]. Dimethoxytritylated compounds were obtained as a white foam in fair to good yield. ${ }^{1} \mathrm{H}$ and ${ }^{13} \mathrm{C}$ NMR data corresponded to the expected values. 7a (U): 90\%, HRMS calcd. for $\mathrm{C}_{32} \mathrm{H}_{35} \mathrm{~N}_{2} \mathrm{O}_{8}[\mathrm{M}+\mathrm{H}]^{+}:$575.2393, found 575.2400; 7b (C): 67\%, HRMS calcd. for $\mathrm{C}_{39} \mathrm{H}_{40} \mathrm{~N}_{3} \mathrm{O}_{8}[\mathrm{M}+\mathrm{H}]^{+}$: 678.2815, found 678.2816; 7c (A): 75\%, HRMS calcd. for $\mathrm{C}_{40} \mathrm{H}_{40} \mathrm{~N}_{5} \mathrm{O}_{7}[\mathrm{M}+\mathrm{H}]^{+}$: 702.2922, found 702.2932; 7d (G): 68\%, HRMS calcd. for $\mathrm{C}_{36} \mathrm{H}_{41} \mathrm{~N}_{6} \mathrm{O}_{7}[\mathrm{M}+\mathrm{H}]^{+}:$669.3036, found 669.3018.

Phosphitylation afforded white powder following precipitation as described: 8a (U): 82\%, HRMS calcd. for $\mathrm{C}_{41} \mathrm{H}_{52} \mathrm{~N}_{4} \mathrm{O}_{9} \mathrm{P}[\mathrm{M}+\mathrm{H}]^{+}$: 775.3472, found 775.3483; ${ }^{31} \mathrm{P}$ NMR: $\mathrm{d}=148.01,150.23$ ppm; 8b (C): 87\%, HRMS calcd. for $\mathrm{C}_{48} \mathrm{H}_{57} \mathrm{~N}_{5} \mathrm{O}_{9} \mathrm{P}[\mathrm{M}+\mathrm{H}]^{+}$: 878.3894, found 878.3909; ${ }^{31} \mathrm{P}$ NMR: $\mathrm{d}=148.16$, 150.62 ppm; 8c (A): 85\%, HRMS calcd. for $\mathrm{C}_{49} \mathrm{H}_{57} \mathrm{~N}_{7} \mathrm{O}_{8} \mathrm{P}[\mathrm{M}+\mathrm{H}]^{+}:$: 902.4006, found 902.4025; ${ }^{31} \mathrm{P}$ NMR: d=147.39, 149.49 ppm; 8d (G): 63\%, HRMS calcd. for $\mathrm{C}_{45} \mathrm{H}_{58} \mathrm{~N}_{8} \mathrm{O}_{8} \mathrm{P}[\mathrm{M}+\mathrm{H}]^{+}$: 869.4115, found 869.4118; ${ }^{31}$ P NMR: $d=148.49,150.29$ ppm;

Oligonucleotide assembly and Purification: Automated assembly was carried out at $1.0 \mu \mathrm{mol}$ scale on an Expedite synthesizer (Applied Biosystems) mainly as described before [12]. An extended 12 min coupling step with the aid of ethyl thiotetrazole $0.25 \mathrm{M}$ as the catalyst and a 14 -fold excess of amidite solution (200 $\mu \mathrm{L}$ of $0.07 \mathrm{M}$ ) was used. Adequate coupling was monitored online by colorimetric quantitation of the trityl fractions. Cleavage from the support and deprotection were performed in one step with AMA at $35^{\circ} \mathrm{C}$ for $2 \mathrm{~h}$. With RNA oligomers, the additional deprotection step was carried out with triethylamine trihydrofluoride as described before [14]. The crude ON solution was desalted on a NAP-25 column and purified by anion-exchange HPLC. The purities and structures of all ON constructs were confirmed by anion-exchange HPLC and HRMS. 
UV melting experiments: UV-melting experiments were recorded with a Cary 100. Experiments on duplexes were achieved with $4 \mu \mathrm{M}$ of each strand in $100 \mathrm{mM} \mathrm{NaCl}$ buffer containing $20 \mathrm{mM} \mathrm{KH}_{2} \mathrm{PO}_{4}$ and 0.1 mM EDTA, pH 7.5. The oligomer concentration was determined by measuring the absorbance at $80^{\circ} \mathrm{C}$ and assuming that extinction coefficients in the denaturated state as used for natural DNA. The absorbance at $260 \mathrm{~nm}$ was continuously monitored over a temperature range from 85 to $15{ }^{\circ} \mathrm{C}$. Specifically, the temperature was initially held at $90^{\circ} \mathrm{C}$ for $5 \mathrm{~min}$, and then decreased to $15^{\circ} \mathrm{C}$, at a rate of $0.5^{\circ} \mathrm{C} \cdot \mathrm{min}^{-1}$. After $5 \mathrm{~min}$ stabilization at $15^{\circ} \mathrm{C}$, the temperature was then raised back to $85^{\circ} \mathrm{C}$ $\left(0.2^{\circ} \mathrm{C} \cdot \mathrm{min}^{-1}\right)$ for melting temperature measurements. All experiments were run at least twice.

Thermodynamic parameter calculation (Tm, $\Delta S^{\circ}, \Delta \boldsymbol{H}^{\circ}$ and $\Delta \boldsymbol{G}^{\circ}{ }_{310}$ ): Dissociation constants $(K(T)$ ) were calculated for duplexes as described by Marky et al. [40] and Durand et al [41]. Hereto, raw optical data are casted into the fraction of the single strand and duplex state at each temperature $\alpha(T)$, for complementary strands binding experiments. The upper and lower absorption baselines $\left(A_{U}\right.$ and $A_{\mathrm{L}}$ ) were determined by calculating the absorbance derivative $(\mathrm{d} A / \mathrm{d} T)$. $A_{\mathrm{U}}$ and $A_{\mathrm{L}}$ values corresponded to both $\mathrm{d} A / \mathrm{d} T$ minima of the curve. Next, the bound fraction parameter $\alpha(T)$ was computed for each temperature $(T)$ according to equation $\mathbf{1}$ :

$\alpha(T)=\left(A_{U}-A(T)\right) /\left(A_{U}-A_{\mathrm{L}}\right)(\mathbf{1})$,

where $A(T)$ is the absorbance at the temperature $T$. Consequently, a plot of $\alpha(T)$ versus temperature was constructed and used to calculate the $T m$ value by interpolating $\alpha=0.5$. The transition equilibrium $K(T)$ was calculated at various temperatures by using the equation $\mathbf{2}$ :

$K(T)=\alpha(T) /\left(\left[C_{\mathrm{T}} / \mathrm{n}\right]^{\mathrm{n}-1}[1-\alpha(T)]^{\mathrm{n}}\right)(2)$

where $\mathrm{n}$ is the number of strands involved in the thermodynamic equilibrium and $C_{\mathrm{T}}$, the sum of their concentrations. In the case of the studied duplexes solution, $n=2$. This equation is only available for non self-complementary duplexes. A Van't Hoff plot of $\operatorname{Ln}(K(T)$ ) versus $1 / T$ was generated for duplex 
formation. The slope and intercept of the calculated line yielded to the enthalpy $\left(\Delta H^{\circ}\right)$ and the entropy $\left(\Delta S^{\circ}\right)$ respectively, according to the equation 3: $\operatorname{Ln}(K(T))=-\left(\Delta H^{\circ} / R\right) \cdot 1 / T+\Delta S^{\circ} / R(3)$,

where $R$ is the gas constant $\left(1.987 \mathrm{cal} \mathrm{K}^{-1} \mathrm{~mol}^{-1}\right)$ and $T$ the temperature in Kelvin. The Gibbs free energy at $310^{\circ} \mathrm{K}\left(\Delta G^{\circ}{ }_{310}\right)$ was calculated according to the equation $4: \Delta G^{\circ}{ }_{310}=\Delta H^{\circ}-310 \cdot \Delta S^{\circ}$ (4).

The obtained data represent the average of at least three independent experiments on duplex formation.

The errors addressed on the thermodynamic data result from the standard deviation of all experiments. Standard deviation calculated for $T \mathrm{~m}$ values are within $\pm 0.2^{\circ} \mathrm{C}$ and those of $\Delta H^{\circ}, \Delta S^{\circ}$ and $\Delta G^{\circ}{ }_{310}$ are within $\pm 3 \%$.

\section{Acknowledgments}

This work was supported by a FWO (Flemish Scientific Research) grant G.0784.N and KU Leuven financial support (GOA/10/13). Mass spectrometry was made possible by the support of the Hercules Foundation of the Flemish Government (grant 20100225-7).

\section{REFERENCES}

1. Dean NM, Bennett CF (2003) Antisense oligonucleotide-based therapeutics for cancer. Oncogene 22:90879096. doi:10.1038/sj.onc.1207231

2. Hammond SM, Boettcher S, Caudy AA, Kobayashi R, Hannon GJ (2001) Argonaute2, a link between genetic and biochemical analyses of RNAi. Science 293:1146-1150. doi:10.1126/science.1064023

3. Martinez J, Patkaniowska A, Urlaub H, Luhrmann R, Tuschl T (2002) Single-stranded antisense siRNAs guide target RNA cleavage in RNAi. Cell 110:563-574. doi:10.1016/S0092-8674(02)00908-X

4. Gregory RI, Chendrimada TP, Cooch N, Shiekhattar R (2005) Human RISC couples microRNA biogenesis and posttranscriptional gene silencing. Cell 123:631-640. doi:10.1016/j.cell.2005.10.022

5. Soutschek J, Akinc A, Bramlage B, Charisse K, Constien R, Donoghue M, Elbashir S, Geick A, Hadwiger P, Harborth J, John M, Kesavan V, Lavine G, Pandey RK, Racie T, Rajeev KG, Rohl I, Toudjarska I, Wang G, Wuschko S, Bumcrot D, Koteliansky V, Limmer S, Manoharan M, Vornlocher H-P (2004) Therapeutic silencing of an endogenous gene by systemic administration of modified siRNAs. Nature 432:173-178.

doi:10.1038/nature03121

6. De Paula D, Bentley MVLB, Mahato RI (2007) Hydrophobization and bioconjugation for enhanced siRNA delivery and targeting. RNA 13:431-456. doi:10.1261/rna.459807

7. Chiu Y-L, Rana TM (2003) siRNA function in RNAi: a chemical modification analysis. RNA 9:1034-1048. doi:10.1261/rna.5103703

8. Mikat V, Heckel A (2007) Light-dependent RNA interference with nucleobase-caged siRNAs. RNA 13:23412347. doi:10.1261/rna.753407 
9. Manoharan M (2004) RNA interference and chemically modified small interfering RNAs. Curr Opin Chem Biol 8:570-579. doi:10.1016/j.cbpa.2004.10.007

10. Van Aerschot A, Verheggen I, Hendrix C, Herdewijn P (1995) 1,5-Anhydrohexitol Nucleic-Acids, a New Promising Antisense Construct. Angew Chem Int Edit 34:1338-1339. doi:10.1002/anie.199513381

11. Hendrix C, Rosemeyer H, Verheggen I, Seela F, Van Aerschot A, Herdewijn P (1997) 1',5'-anhydrohexitol oligonucleotides: Synthesis, base pairing and recognition by regular oligodeoxyribonucleotides and oligoribonucleotides. Chem-Eur J 3:110-120. doi:10.1002/chem.19970030118

12. Allart B, Khan K, Rosemeyer H, Schepers G, Hendrix C, Rothenbacher K, Seela F, Van Aerschot A, Herdewijn P (1999) D-Altritol nucleic acids (ANA): Hybridisation properties, stability, and initial structural analysis. Chem-Eur J 5:2424-2431. doi:10.1002/(SICI)1521-3765(19990802)5:8<2424::AID-

CHEM2424>3.0.CO;2-W

13. Wang J, Verbeure B, Luyten I, Lescrinier E, Froeyen M, Hendrix C, Rosemeyer H, Seela F, Van Aerschot A, Herdewijn P (2000) Cyclohexene nucleic acids (CeNA): Serum stable oligonucleotides that activate RNase H and increase duplex stability with complementary RNA. J Am Chem Soc 122:8595-8602.

doi:10.1021/Ja000018+

14. D'Alonzo D, Van Aerschot A, Guaragna A, Palumbo G, Schepers G, Capone S, Rozenski J, Herdewijn P (2009) Synthesis and Base Pairing Properties of 1 ',5 '-Anhydro-L-Hexitol Nucleic Acids (L-HNA). Chem-Eur J 15:10121-10131. doi:10.1002/chem.200901847

15. Martin P (1995) Ein neuer Zugang zu 2' -O-Alkylribonucleosiden und Eigenschaften deren

Oligonucleotide. Helv Chim Acta 78:486-504. doi:10.1002/hlca.19950780219

16. Prakash TP, Bhat B (2007) 2'-Modified oligonucleotides for antisense therapeutics, vol 7. Curr Top Med Chem, vol 17430205.

17. Tarköy M, Bolli M, Schweizer B, Leumann C (1993) Nucleic-Acid Analogues with Constraint Conformational Flexibility in the Sugar-Phosphate Backbone ( 'Bicyclo-DNA' ). Part 1. Preparation of

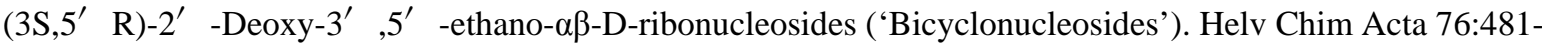
510. doi:10.1002/hlca.19930760132

18. Singh SK, Nielsen P, Koshkin AA, Wengel J (1998) LNA (locked nucleic acids): synthesis and high-affinity nucleic acid recognition. Chem Commun:455-456. doi:10.1039/A708608C

19. Veedu RN, Wengel J (2010) Locked nucleic acids: promising nucleic acid analogs for therapeutic applications. Chem Biodivers 7:536-542. doi:10.1002/cbdv.200900343

20. Herdewijn P (1996) Targeting RNA with conformationally restricted oligonucleotides. Liebigs Ann:13371348. doi:10.1002/jlac.199619960902

21. Herdewijn P (2010) Nucleic acids with a six-membered 'carbohydrate' mimic in the backbone. Chem Biodivers 7:1-59. doi:10.1002/cbdv.200900185

22. Hendrix C, Rosemeyer H, De Bouvere B, Van Aerschot A, Seela F, Herdewijn P (1997) 1',5'-anhydrohexitol oligonucleotides: Hybridisation and strand displacement with oligoribonucleotides, interaction with RNase $\mathrm{H}$ and HIV reverse transcriptase. Chem-Eur J 3:1513-1520. doi:10.1002/chem.19970030920

23. Vandermeeren M, Preveral S, Janssens S, Geysen J, Saison-Behmoaras E, Van Aerschot A, Herdewijn P (2000) Biological activity of hexitol nucleic acids targeted at Ha-ras and intracellular adhesion molecule-1 mRNA. Biochem Pharmacol 59:655-663. doi:10.1016/S0006-2952(99)00367-6

24. Fisher M, Abramov M, Van Aerschot A, Xu D, Juliano RL, Herdewijn P (2007) Inhibition of MDR1 expression with altritol-modified siRNAs. Nucleic Acids Res 35:1064-1074. doi:10.1093/nar/gkl1126 25. Fisher M, Abramov M, Van Aerschot A, Rozenski J, Dixit V, Juliano RL, Herdewijn P (2009) Biological effects of hexitol and altritol-modified siRNAs targeting B-Raf. Eur J Pharmacol 606:38-44.

doi:10.1016/j.ejphar.2009.01.030

26. Ovaere M, Sponer J, Sponer JE, Herdewijn P, Van Meervelt L (2012) How does hydroxyl introduction influence the double helical structure: the stabilization of an altritol nucleic acid:ribonucleic acid duplex. Nucleic Acids Res 40:7573-7583. doi:10.1093/nar/gks470

27. Van Aerschot A, Meldgaard M, Schepers G, Volders F, Rozenski J, Busson R, Herdewijn P (2001) Improved hybridisation potential of oligonucleotides comprising O-methylated anhydrohexitol nucleoside congeners. Nucleic Acids Res 29:4187-4194. doi:10.1093/nar/29.20.4187

28. Lamond AI, Sproat BS (1993) Antisense oligonucleotides made of 2'-O-alkylRNA: their properties and applications in RNA biochemistry. FEBS Lett 325:123-127. doi:10.1016/0014-5793(93)81427-2 
29. Sproat BS, Lamond AI, Beijer B, Neuner P, Ryder U (1989) Highly efficient chemical synthesis of 2'-Omethyloligoribonucleotides and tetrabiotinylated derivatives; novel probes that are resistant to degradation by RNA or DNA specific nucleases. Nucleic Acids Res 17:3373-3386. doi:10.1093/nar/17.9.3373 30. Abramov M, Herdewijn P (2007) Synthesis of altritol nucleoside phosphoramidites for oligonucleotide synthesis. Curr Protoc Nucleic Acid Chem Chapter 1:Unit 1 18. doi:10.1002/0471142700.nc0118s30 31. Teste K, Colombeau L, Hadj-Bouazza A, Lucas R, Zerrouki R, Krausz P, Champavier Y (2008) Solventcontrolled regioselective protection of 5 '-O-protected thymidine. Carbohydr Res 343:1490-1495. doi:10.1016/j.carres.2008.04.026

32. Lucas R, Teste K, Zerrouki R, Champavier Y, Guilloton M (2010) Chelation-controlled regioselective alkylation of pyrimidine 2 '-deoxynucleosides. Carbohydr Res 345:199-207. doi:10.1016/j.carres.2009.10.021 33. Divakar KJ, Reese CB (1982) 4-(1,2,4-Triazol-1-yl) and 4-(3-Nitro-1,2,4-Triazol-1-yl)-1-(Beta-D-2,3,5-TriO-Acetylarabinofuranosyl)Pyrimidin-2(1h)-Ones - Valuable Intermediates in the Synthesis of Derivatives of "1(Beta-D-Arabinofuranosyl)Cytosine (Ara-C). J Chem Soc Perk T 1:1171-1176. doi:10.1039/P19820001171 34. Ott G, Arnold L, Smrt J, Sobkowski M, Limmer S, Hofmann HP, Sprinzl M (1994) The Chemical Synthesis of Biochemically Active Oligoribonucleotides Using Dimethylaminomethlene Protected Purine H-Phosphonates. Nucleosides Nucleotides 13:1069-1085. doi:10.1080/15257779408011880

35. Van Aerschot A, Saison-Behmoaras E, Rozenski J, Hendrix C, Schepers G, Verhoeven G, Herdewijn P (1995). Bull Soc Chim Belge 104:717. doi:10.1002/bscb.19951041208

36. Chatelain G, Brisset H, Chaix C (2009) A thermodynamic study of ferrocene modified hairpin oligonucleotides upon duplex formation: applications to the electrochemical detection of DNA. New J Chem 33:1139-1147. doi:10.1039/B817057f

37. Chatelain G, Meyer A, Morvan F, Vasseur JJ, Chaix C (2011) Electrochemical detection of nucleic acids using pentaferrocenyl phosphoramidate alpha-oligonucleotides. New J Chem 35:893-901.

doi:10.1039/C0nj00902d

38. Bhattacharyya J, Maiti S, Muhuri S, Nakano S-i, Miyoshi D, Sugimoto N (2011) Effect of locked nucleic acid modifications on the thermal stability of noncanonical DNA structure. Biochemistry (Mosc) 50:7414-7425. doi:10.1021/bi200477g

39. Bramsen JB, Laursen MB, Nielsen AF, Hansen TB, Bus C, Langkjaer N, Babu BR, Hojland T, Abramov M, Van Aerschot A, Odadzic D, Smicius R, Haas J, Andree C, Barman J, Wenska M, Srivastava P, Zhou CZ, Honcharenko D, Hess S, Muller E, Bobkov GV, Mikhailov SN, Fava E, Meyer TF, Chattopadhyaya J, Zerial M, Engels JW, Herdewijn P, Wengel J, Kjems J (2009) A large-scale chemical modification screen identifies design rules to generate siRNAs with high activity, high stability and low toxicity. Nucleic Acids Res 37:2867-2881. doi:10.1093/Nar/Gkp106

40. Marky LA, Kallenbach NR, McDonough KA, Seeman NC, Breslauer KJ (1987) The melting behavior of a DNA junction structure: a calorimetric and spectroscopic study. Biopolymers 26:1621-1634. doi:10.1002/bip.360260912

41. Durand M, Chevrie K, Chassignol M, Thuong NT, Maurizot JC (1990) Circular dichroism studies of an oligodeoxyribonucleotide containing a hairpin loop made of a hexaethylene glycol chain: conformation and stability. Nucleic Acids Res 18:6353-6359. doi:10.1093/nar/18.21.6353 


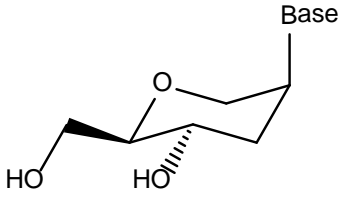

HNA<smiles>COC1CO[C@H](CO)[C@@H](O)C1n1ccc(=O)[nH]c1=O</smiles>

1a, maU

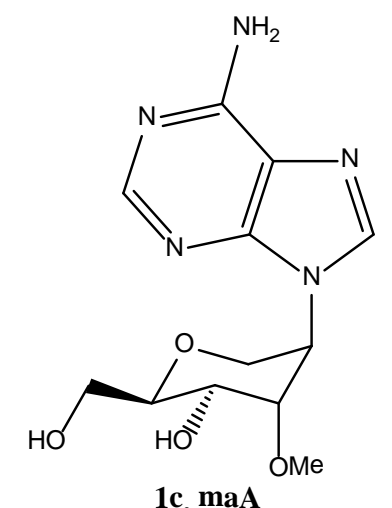

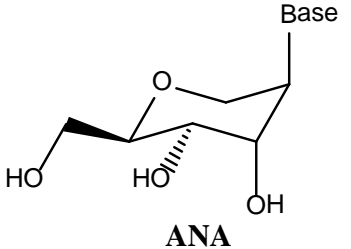<smiles>COC1CO[C@H](CO)[C@@H](O)C1n1ccc(N)nc1=O</smiles>

1b, maC<smiles>COC1CO[C@H](CO)[C@@H](O)C1n1cnc2c(=O)[nH]c(N)nc21</smiles>

1d, maG

Fig. 1: General structure for hexitol (HNA) and altritol (ANA) nucleoside analogues and for the four new methylated altritol congeners (maX) which oligomerize into MANA. 

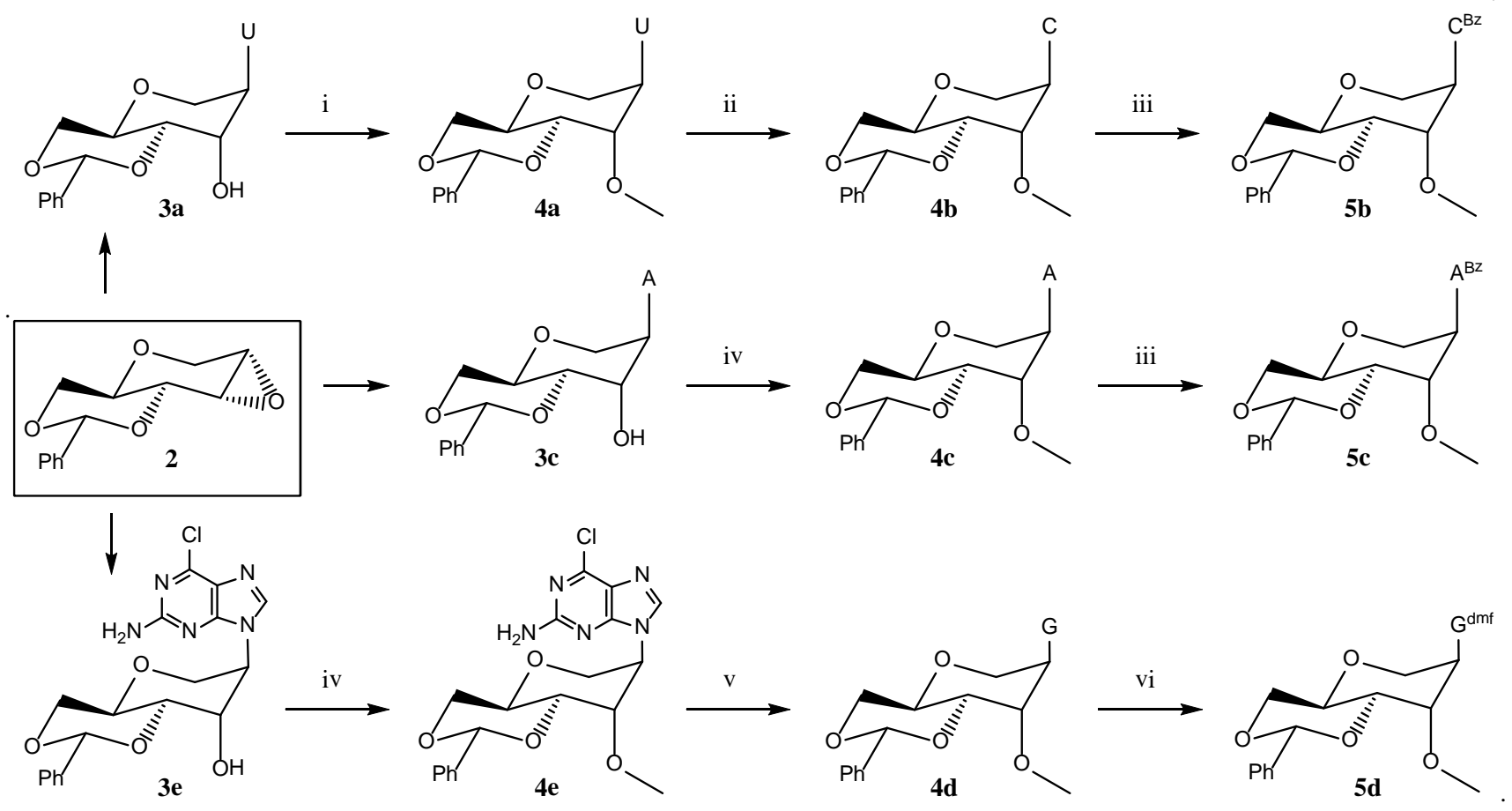

Fig. 2: Synthesis of the base-protected 3'-O-methylated altritol congeners $\mathbf{4 a}, \mathbf{5 b}, \mathbf{5 c}$ and $\mathbf{5 d}$. Conditions: i. NaH, MeI, THF, 3h, $0^{\circ} \mathrm{C}$; ii. 1,2,4-1H-triazole, phosphorus oxichloride, pyridine, triethylamine; iii. Benzoyl chloride, pyridine, 16h, rt; iv. NaH, MeI, DMF, 3h, $-20^{\circ} \mathrm{C}$; v. $\mathrm{NaOH}$, DABCO, water, $5 \mathrm{~h}, 90^{\circ} \mathrm{C}$; vi. Dmf(OEt) $)_{2}$, DMF, $16 \mathrm{~h}$, rt.

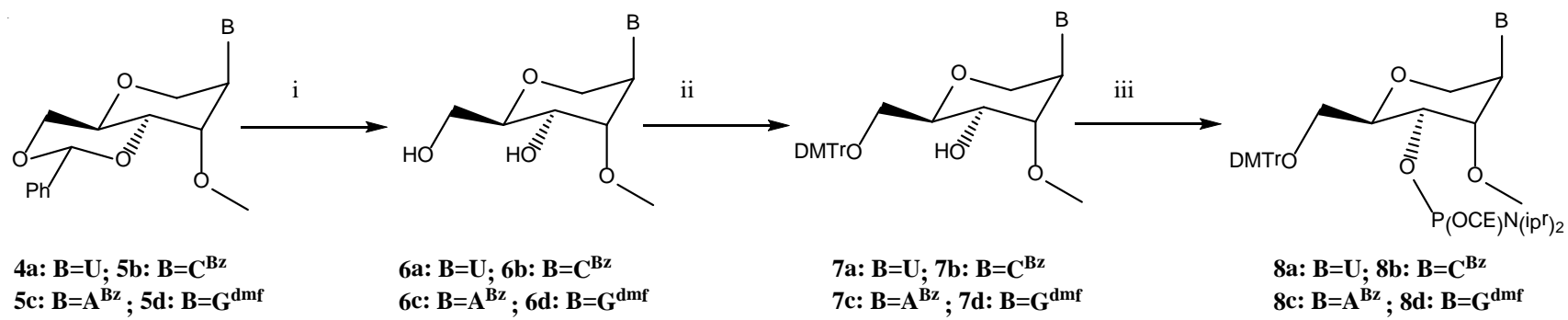

Fig. 3: Synthesis of the MANA phosphoramidites 8a-8d. Conditions: i. TFA, DCM, water, pyridine, $0^{\circ} \mathrm{C}$; ii. DMTrCl, pyridine, rt; iii. DIPEA, DCM, (iPr $)_{2} \mathrm{~N}(\mathrm{OCE}) \mathrm{PCl}, 0^{\circ} \mathrm{C}$. 


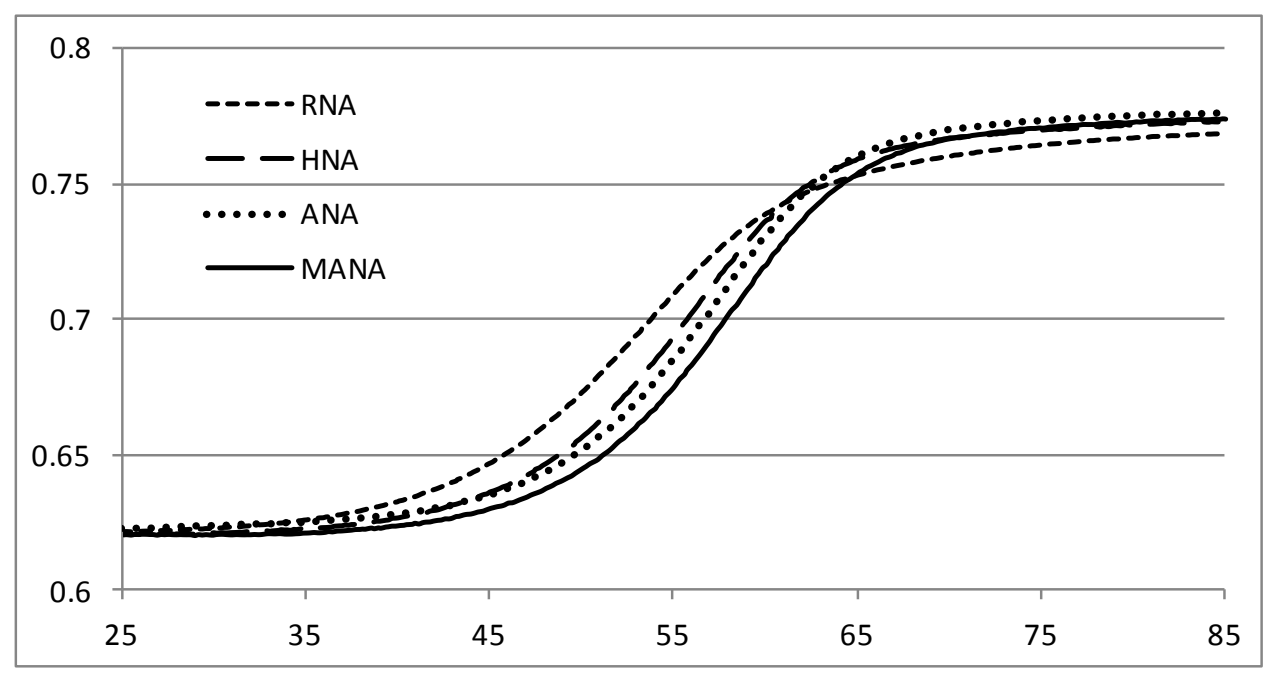

Fig. 4: Superimposed Tm curves for RNA duplexes [5'-GCGU-U*-UGCG / 5'-CGCAAACGC] with a single hexitol modification $\left(\mathrm{U}^{*}\right)$ denoting either a HNA, ANA or MANA uridine monomer. For experimental conditions see text.

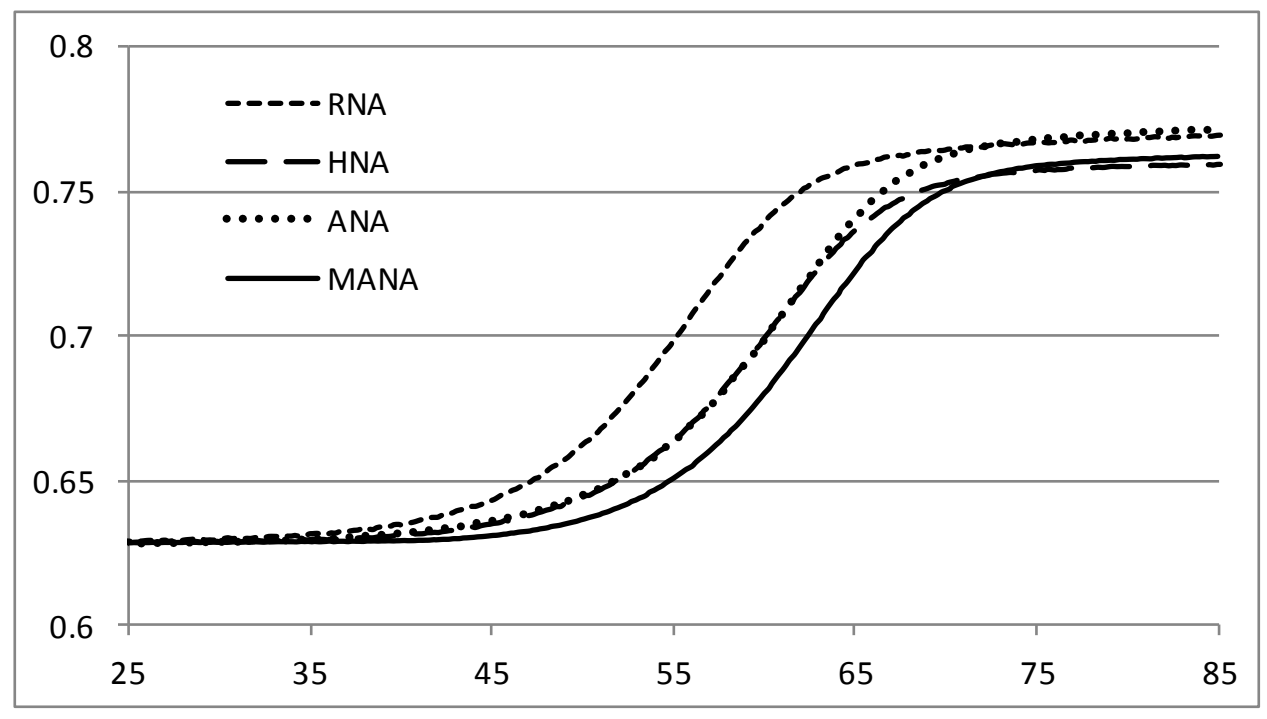

Fig. 5: Superimposed Tm curves for RNA duplexes [5'-GC-U*-GUG-U*-CG) / 5'-CGACACAGC] containing two hexitol modifications ( $\mathrm{U}^{*}$ ) denoting either a HNA, ANA or MANA uridine monomer. For experimental conditions see text. 


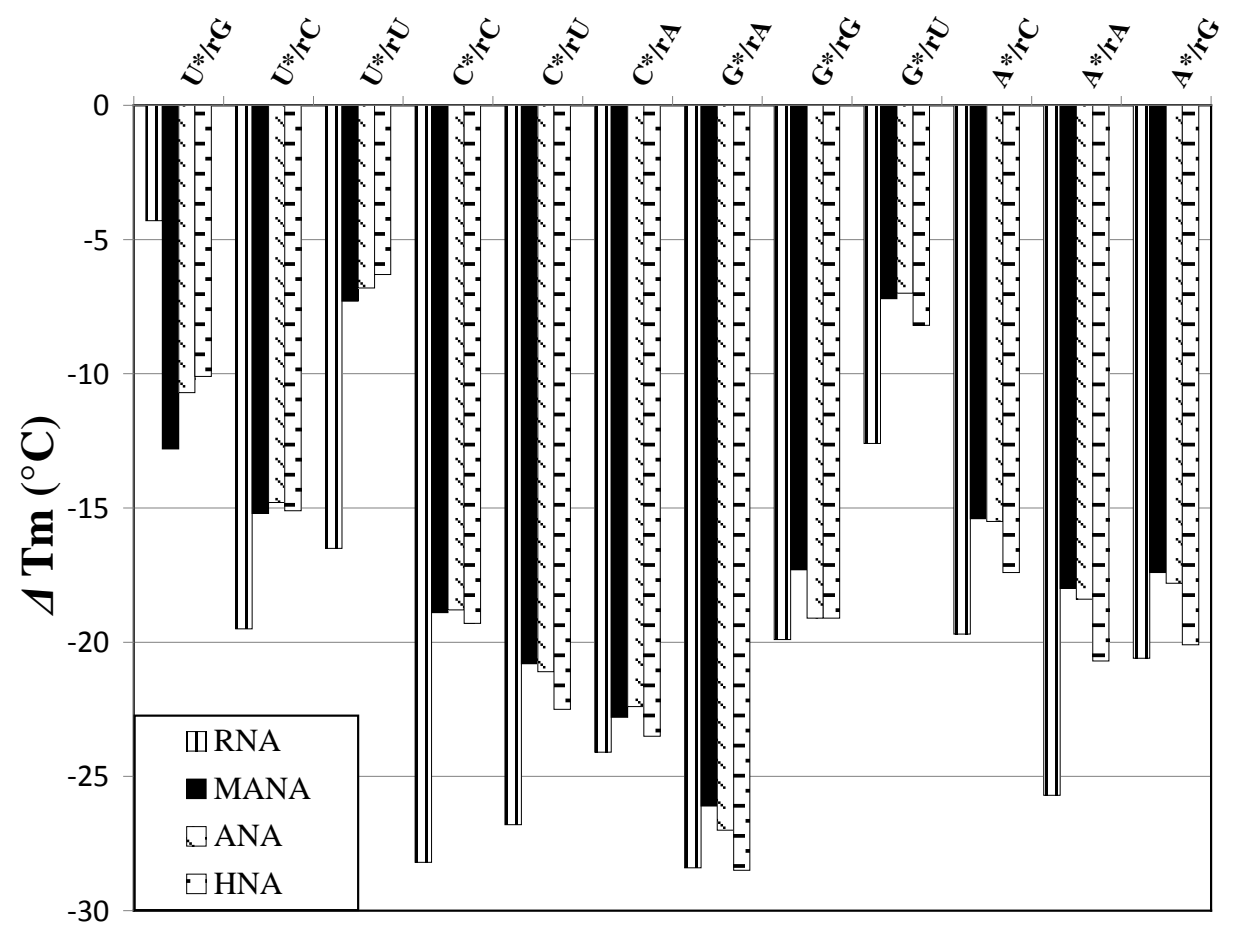

Fig. 6: Thermal stability of RNA sequences with a single modification of MANA, ANA or HNA analogs versus one mismatched RNA. The RNA sequence 5'-GCGU-X*-UGCG-3' has been used for these experimentations. Tm values in $100 \mathrm{mM} \mathrm{NaCl}$ buffer containing $20 \mathrm{mM} \mathrm{KH}_{2} \mathrm{PO}_{4}$ and $0.1 \mathrm{mM}$ EDTA, pH 7.5, with a duplex concentration of $4 \mu \mathrm{M}$. U*, $\mathrm{C}^{*}, \mathrm{~A}^{*}$ and $\mathrm{G}^{*}$ denote either a RNA, a MANA, a ANA or a HNA monomer. 
Table 1: Thermal and thermodynamic data for ONs containing either a MANA, ANA or HNA modification $X^{*}$ hybridized to their respective complementary RNA sequence [5'-GCGU-X*-UGCG / 5'-CGCAYACGC].

\begin{tabular}{clcccc}
\hline $\mathrm{X}^{*}$ & Structure & $\mathrm{Tm}\left({ }^{\circ} \mathrm{C}\right)$ & $\Delta \mathrm{H}^{\circ}\left(\mathrm{kCal} . \mathrm{mol}^{-1}\right)$ & $\Delta \mathrm{S}^{\circ}\left(\mathrm{Cal}_{\mathrm{mol}}{ }^{-1}\right)$ & $\Delta \mathrm{G}^{\circ}{ }_{310}\left(\mathrm{kCal} . \mathrm{mol}^{-1}\right)$ \\
\hline \multirow{4}{*}{$\mathrm{U}$} & RNA & $50.4 \pm 0.0$ & $-67.5 \pm 1.5$ & $-181.8 \pm 4.8$ & $-45.6 \pm 0.3$ \\
& MANA & $53.8 \pm 0.2$ & $-73.6 \pm 1.9$ & $-199.1 \pm 5.6$ & $-49.7 \pm 0.6$ \\
& ANA & $53.0 \pm 0.2$ & $-68.8 \pm 1.8$ & $-184.9 \pm 5.3$ & $-48.0 \pm 0.6$ \\
& HNA & $53.4 \pm 0.1$ & $-70.1 \pm 1.0$ & $-188.5 \pm 2.9$ & $-48.7 \pm 0.3$ \\
& RNA & $60.8 \pm 0.1$ & $-88.8 \pm 1.9$ & $-239.8 \pm 5.7$ & $-60.5 \pm 0.5$ \\
$\mathrm{C}$ & MANA & $61.4 \pm 0.0$ & $-90.1 \pm 1.2$ & $-243.0 \pm 3.6$ & $-61.5 \pm 0.4$ \\
& ANA & $60.9 \pm 0.1$ & $-85.7 \pm 1.0$ & $-230.5 \pm 3.1$ & $-59.4 \pm 0.3$ \\
& HNA & $62.0 \pm 0.0$ & $-100.1 \pm 2.4$ & $-272.4 \pm 3.2$ & $-65.4 \pm 0.8$ \\
& & & & & \\
$\mathrm{G}$ & RNA & $60.4 \pm 0.0$ & $-88.3 \pm 1.4$ & $-238.4 \pm 4.1$ & $-59.9 \pm 0.4$ \\
& MANA & $63.4 \pm 0.1$ & $-92.1 \pm 1.3$ & $-247.6 \pm 3.9$ & $-64.2 \pm 0.4$ \\
& ANA & $62.9 \pm 0.0$ & $-95.9 \pm 1.1$ & $-259.2 \pm 3.4$ & $-64.9 \pm 0.4$ \\
& HNA & $62.4 \pm 0.1$ & $-91.3 \pm 1.9$ & $-246.1 \pm 5.7$ & $-62.8 \pm 0.7$ \\
& RNA & $52.5 \pm 0.1$ & $-67.8 \pm 1.7$ & $-182.1 \pm 5.3$ & $-47.5 \pm 0.4$ \\
\multirow{4}{*}{ A } & MANA & $57.0 \pm 0.1$ & $-82.2 \pm 1.8$ & $-222.7 \pm 5.4$ & $-54.7 \pm 0.5$ \\
& ANA & $56.5 \pm 0.1$ & $-85.6 \pm 2.3$ & $-233.5 \pm 7.1$ & $-55.2 \pm 0.6$ \\
& HNA & $55.0 \pm 0.2$ & $-79.9 \pm 0.9$ & $-217.4 \pm 2.6$ & $-52.3 \pm 0.5$ \\
\hline
\end{tabular}

Tm values in $100 \mathrm{mM} \mathrm{NaCl}$ buffer containing $20 \mathrm{mM} \mathrm{KH}_{2} \mathrm{PO}_{4}$ and $0.1 \mathrm{mM}$ EDTA, pH 7.5, with a duplex concentration of $4 \mu \mathrm{M}$. Annotations $\mathrm{U}^{*}, \mathrm{C}^{*}$, $\mathrm{A}^{*}$ and $\mathrm{G}^{*}$ denote either a MANA, a ANA or HNA monomer, respectively. 
Table 2: Thermal stability of RNA sequences with a double modification $\mathbf{X}^{*}$ of either MANA, ANA or HNA constructs versus the respective complementary RNA sequence.

\begin{tabular}{cccc}
\hline Sequences & X* & $\operatorname{Tm}\left({ }^{\circ} \mathrm{C}\right)$ & $\Delta \mathrm{Tm} /$ modif. $\left({ }^{\circ} \mathrm{C}\right)$ \\
\hline & RNA & $55,6 \pm 0.4$ & Reference \\
5'-GC U* GUG U* CG-3' & MANA & $62,6 \pm 0.2$ & 3,5 \\
& ANA & $61,2 \pm 0.2$ & 2,8 \\
& HNA & $60,2 \pm 0.1$ & 2,3 \\
5'-GC C* AUA C* CG-3' & RNA & $57,1 \pm 0.1$ & Reference \\
& ANA & $59,3 \pm 0.1$ & 1,1 \\
& HNA & $58,5 \pm 0.1$ & 0,7 \\
& RNA & $51,2 \pm 0.1$ & 0,6 \\
5'-GC G* UUU G* CG-3' & MANA & $54,3 \pm 0.1$ & Reference \\
& ANA & $54,1 \pm 0.1$ & 1,5 \\
& HNA & $53,0 \pm 0.2$ & 1,4 \\
& RNA & $57,1 \pm 0.1$ & Reference \\
& MANA & $63,5 \pm 0.1$ & 3,2 \\
5'-GC A* CUC A* CG-3' & ANA & $62,1 \pm 0.1$ & 2,5 \\
& HNA & $62,1 \pm 0.1$ & 2,5 \\
& RNA & $40,6 \pm 0.1$ & Reference \\
& MANA & $61,1 \pm 0.3$ & 2,6 \\
5'-G*C*G* U*A*G* C*G*-3' & ANA & $59,6[27]$ & 2,4 \\
& HNA & $52,0[27]$ & 1,4 \\
\hline
\end{tabular}

Tm values in $100 \mathrm{mM} \mathrm{NaCl}$ buffer containing $20 \mathrm{mM} \mathrm{KH}_{2} \mathrm{PO}_{4}$ and $0.1 \mathrm{mM}$ EDTA, pH 7.5, with a duplex concentration of $4 \mu \mathrm{M}$. U*, $\mathrm{C}^{*}, \mathrm{~A}^{*}$ and $\mathrm{G}^{*}$ denote either a RNA, a MANA, a ANA or a HNA monomer, respectively. 